\title{
Sub-tropical seagrass ecosystem metabolism measured by eddy covariance
}

\author{
Matthew H. Long ${ }^{1,2, *}$, Peter Berg ${ }^{1}$, Karen J. McGlathery ${ }^{1}$, Joseph C. Zieman ${ }^{1}$ \\ ${ }^{1}$ Department of Environmental Sciences, University of Virginia, 291 McCormick Rd, Charlottesville, Virginia 22904, USA \\ ${ }^{2}$ Present address: Department of Marine Chemistry and Geochemistry, Woods Hole Oceanographic Institution, \\ 266 Woods Hole Road, Woods Hole, Massachusetts 02543, USA
}

\begin{abstract}
The metabolism of seagrass ecosystems was examined at 4 sites in south Florida, USA, using the eddy covariance technique under in situ conditions. Three sites were located across a phosphorus-driven productivity gradient to examine the combined effects of dynamic variables (irradiance, flow velocity) and state variables (sediment phosphorus and organic content, seagrass biomass) on ecosystem metabolism and trophic status. Gross primary production and respiration rates varied significantly across Florida Bay in the summer of 2012 with the lowest rates (64 and $-53 \mathrm{mmol} \mathrm{O}_{2} \mathrm{~m}^{-2} \mathrm{~d}^{-1}$, respectively) in low-phosphorus sediments in the northeast and the highest (287 and $-212 \mathrm{mmol} \mathrm{O}_{2} \mathrm{~m}^{-2} \mathrm{~d}^{-1}$, respectively) in the southwest where sediment phosphorus, organic matter, and seagrass biomass are higher. Seagrass ecosystems offshore of the Florida Keys had similar large daily production and respiration rates $\left(397\right.$ and $-217 \mathrm{mmol} \mathrm{O} \mathrm{m}^{-2} \mathrm{~d}^{-1}$, respectively) and were influenced by flow through the permeable offshore sediments. Across all sites, net ecosystem metabolism rates indicated that the seagrass ecosystems were autotrophic in the summertime. Substantial day-to-day variability in metabolic rates was found due to variations in irradiance and flow velocity. At all sites the relationship between photosynthesis and irradiance was linear and did not show any sign of saturation over the entire irradiance range (up to $1400 \mu \mathrm{mol}$ photons $\mathrm{m}^{-2} \mathrm{~s}^{-1}$ ). This was likely due to the efficient use of light by the large photosynthetic surface area of the seagrass canopy, an effect which can only be examined by in situ measurements that integrate across all autotrophs in the seagrass ecosystem.
\end{abstract}

KEY WORDS: Seagrass · Eddy covariance $\cdot$ Metabolism $\cdot$ Carbon cycling

\section{INTRODUCTION}

Seagrass communities are some of the most productive coastal marine ecosystems (Duarte et al. 2010, Fourqurean et al. 2012), and the seagrass meadows of south Florida are among the largest on Earth (Zieman 1989, Fourqurean \& Zieman 2002). They are a significant component of global marine carbon (C) and nutrient cycling due to their high areal coverage, high productivity, and efficiency in the burial of organic matter (Duarte et al. 2010, Fourqurean et al. 2012). The seagrass canopy slows water velocities and causes particulate deposition, resulting in the accumulation of organic matter and sediments (Fonseca \& Fisher 1986, Gacia \& Duarte 2001). Decreased seagrass biomass and density may have the primary effect of increasing suspended sediments and reducing light, and secondarily, of reducing available sediment nutrients through a decrease in organic matter. Consequently, dynamic interactions exist between irradiance, turbidity, nutrients, and productivity where the combined effects of these parameters control the metabolism and community structure of seagrass meadows.

The efficient capture of irradiance by the vertical structure of the seagrass canopy, combined with their 
ability to thrive under oligotrophic conditions, allows seagrass ecosystems to dominate total ecosystem productivity in shallow waters (Duarte 1995). The amount of photosynthetic surface area per square meter of benthic surface and the degree of self-shading determines the efficiency of irradiance capture for the seagrass ecosystem as a whole (Zimmerman 2003, Ralph et al. 2007). For example, in dense seagrass meadows, irradiance reaching seagrass canopies is efficiently captured at rates of up to $90 \%$ (Zimmerman 2003, Enriquez \& Pantoja-Reyes 2005). Self-shading reduces the amount of direct or downwelling irradiance penetrating the canopy while increasing diffuse irradiance, thus reducing light saturation of the canopy as a whole (Enriquez et al. 2002, Gacia et al. 2012). This is reflected in seagrass photosynthetic pigments where low-irradiance portions of seagrasses have more pigments to compensate for the reduced intra-canopy irradiance (Durako \& Kunzelman 2002, Cayabyab \& Enriquez 2007, Mackey et al. 2007). Seagrasses also show morphological plasticity that enables them to vary shoot density and leaf length to optimize light gathering and exploitation (Enriquez et al. 2002, Enriquez \& Pantoja-Reyes 2005, Cayabyab \& Enriquez 2007). The efficiency of irradiance capture is also increased when integrating across all benthic communities present in seagrass meadows including seagrasses, macroalgae, benthic microalgae, and epiphytes. Including all benthic communities and their interactions in metabolic measurements may result in photosynthetic rates that do not saturate at high irradiances, an effect that may not be observed by examining the individual components of the ecosystem (Binzer et al. 2006, SandJensen et al. 2007). Therefore, in situ ecosystem-level analysis of complex benthic systems is highly important in determining accurate rates of metabolism.

A series of environmental gradients exists across the Florida Keys seagrass meadows where generally the lowest amounts of seagrass biomass, sediment organic matter, and phosphorus are present in northeastern Florida Bay and the highest amounts are present in the southwestern Florida Bay and offshore (Zieman 1989, Fourqurean \& Zieman 2002, Long et al. 2008). These gradients produce seagrasses in the northeast of the bay that experience very little shading due to their low densities and reduced biomass while the high-density and biomass seagrasses in the southwest have a high degree of self-shading. Phosphorus is the primary limiting nutrient in Florida Bay due to phosphorus adsorption by the carbonate sediments and the long residence time of water, especially in the northeast of the bay where land masses limit water exchange with the Gulf of Mexico (Fourqurean \& Zieman 2002, Long et al. 2008). The higher phosphorus availability in the southwest part of the bay supports greater seagrass biomass, which is directly related to the deposition of sediments and organic matter by the reduction of flow at the sediment surface (Fonseca \& Fisher 1986, Gacia \& Duarte 2001).

The metabolism of seagrasses, as well as other organisms within the seagrass ecosystem, has been shown to be strongly affected by flow velocity (Fonseca \& Kenworthy 1987, Mass et al. 2010, Hume et al. 2011), and therefore in situ analysis of seagrass meadow metabolism is the only means to accurately determine productivity. The eddy covariance (EC) technique is becoming a popular tool for measuring benthic flux rates in situ because of its high temporal resolution, large area of measurement, and adaptability to many different benthic systems (Berg et al. 2003). The EC technique correlates instantaneous changes in the vertical velocity and oxygen $\left(\mathrm{O}_{2}\right)$ concentration at a point in the water column and integrates the product of these changes over time to calculate benthic flux rates (Berg et al. 2003). It has been compared to and validated by chamber measurements (Berg et al. 2003, Glud et al. 2010, Johnson et al. 2011) and electrode profiling measurements (Berg et al. 2003, Berg et al. 2009, Brand et al. 2008), and has yielded high temporal resolution data that produced reliable and higher-quality metabolic measurements than standard techniques (Berg et al. 2003, Berg et al. 2013). Studies on the metabolic rates of temperate seagrass ecosystems using the EC technique have determined that short-term changes in flow and light are significant drivers of ecosystem metabolism (Hume et al. 2011, Rheuban et al. 2014a,b). Rheuban et al. (2014a) also highlighted that multiple timescale processes influence metabolism, from hourly variations in velocity to seasonal changes in seagrass density and water temperature.

This study represents the first in situ analysis of sub-tropical seagrass ecosystem metabolism using the EC technique. We hypothesized (1) that the rates of primary production and respiration of the seagrass ecosystem would increase with larger quantities of seagrass biomass, sediment organic matter, and phosphorus, consistent with the nutrient-driven biomass gradient of Florida Bay, (2) that dynamic variables, such as light and flow velocity, would be the dominant drivers of short-term metabolic variability, and (3) that the interactions of light and flow with the changing seagrass canopy structure across the biomass gradient would lead to different light capture 


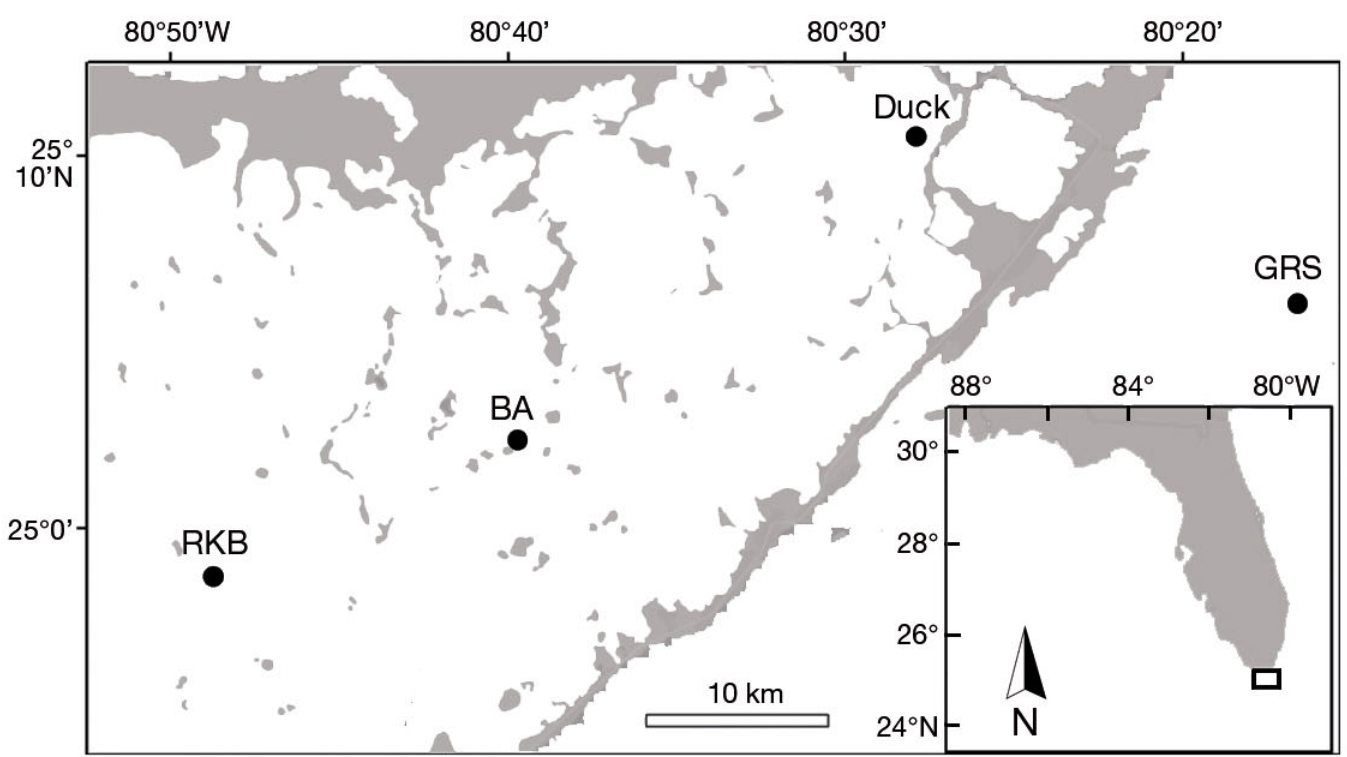

Fig. 1. Top panel: Locations of the sites RKB, BA, and Duck across Florida Bay, and the offshore site GRS, all at the southern tip of Florida. Lower panels show typical conditions at each bay site; numbers above them are the aboveground biomass $( \pm \mathrm{SE})$. The measuring volume of the instrument at the tip of the $\mathrm{O}_{2}$ sensor is located at 55, 35, and $35 \mathrm{~cm}$ above the sediment surface for RKB, BA, and Duck, respectively. The offshore site GRS had the largest biomass of $193 \pm$ $39 \mathrm{~g}^{\mathrm{d} r y} \mathrm{wt} \mathrm{m} \mathrm{m}^{-2}$
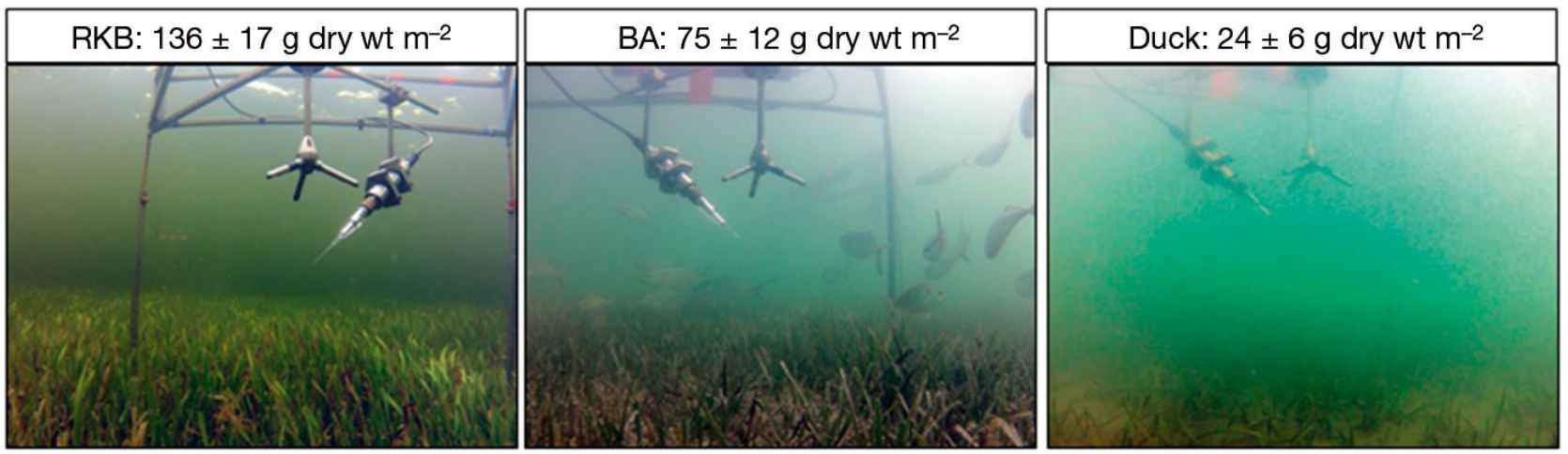

efficiencies and therefore higher rates of autotrophy with higher seagrass biomass. The analysis presented here examines the $\mathrm{O}_{2}$ metabolism of the complete seagrass ecosystem, utilizing the EC technique, which integrates across all organisms within the seagrass canopy and the underlying sediment.

\section{MATERIALS AND METHODS}

\section{Study sites}

The study sites for this research were located in the shallow estuary of Florida Bay and Grecian Rocks Sanctuary Protection Area (GRS) within the Florida Keys National Marine Sanctuary, both in south Florida, USA. Three sites in Florida Bay were used across a well-established productivity and nutrient gradient where phosphorus is the primary limiting nutrient (Zieman 1989, Fourqurean \& Zieman 1992, Fourqurean \& Zieman 2002) in July and August of 2012. Sites were selected to span this gradient with the lowest amounts of seagrass biomass, sediment organic matter, and sediment and porewater phosphate at the northeast site of Duck Key (Duck) and the highest at the southwest site of Rabbit Key Basin (RKB) (Long et al. 2008). The bay sites had monotypic beds of the seagrass Thalassia testudinum growing in fine-grained carbonate muds with similar depths (1.7 to $1.9 \mathrm{~m}$ average depth) and were located at

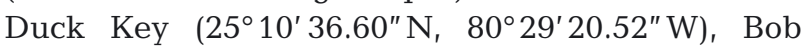
Allen Keys (BA) $\left(25^{\circ} 2^{\prime} 9.27^{\prime \prime} \mathrm{N}, 80^{\circ} 41^{\prime} 10.66^{\prime \prime} \mathrm{W}\right)$, and

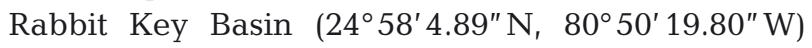
(Fig. 1). The offshore seagrass site, within GRS (Fig. 1; $25^{\circ} 06^{\prime} 38^{\prime \prime} \mathrm{N}, 80^{\circ} 18^{\prime} 28^{\prime \prime} \mathrm{W}$ ), was sampled in July and August of 2010. This site was on average $3.5 \mathrm{~m}$ deep and was located $200 \mathrm{~m}$ inshore of a shallow coral reef where metabolism has been assessed previously by EC (Long et al. 2013). The benthic surface at the offshore site was similarly dominated by T. testudinum growing in coarse sands.

The sediment characteristics at the bay sites were determined from 4 replicate sediment cores $(0.1 \mathrm{~m}$ diameter $\times 0.3 \mathrm{~m}$ depth). No sediment cores were col- 
lected at the offshore site. The percentage of organic matter was determined by weight loss after combusting at $450^{\circ} \mathrm{C}$ for $5 \mathrm{~h}$, after the removal of inorganic carbon using $1 \mathrm{~N}$ hydrochloric acid. Total sediment phosphorus was determined by the persulfate digestion method described by Koroleff (1983). Sediment porewater samples were collected at $15 \mathrm{~cm}$ depth using a small-diameter stainless steel probe and the method described by Berg \& McGlathery (2001). The samples were filtered using $0.45 \mu \mathrm{m}$ syringe filters, frozen, and analyzed for phosphate on a Lachat autoanalyzer (QuikChem 8500 Automated Ion Analyzer).

\section{Eddy covariance measurements}

The EC systems consisted of an acoustic Doppler velocimeter (Nortek AS) connected to a fast-responding (<0.3 s) Clark-type $\mathrm{O}_{2}$ microsensor (Revsbech 1989) through a custom-made picoamp amplifier (Berg et al. 2003) or a simple amplifier (McGinnis et al. 2011). All components were attached to a triangular frame that was designed to minimize flow disturbance (Fig. 1). The 3-dimensional velocity field was measured in a $\sim 2.1 \mathrm{~cm}^{3}$ measuring volume and the $\mathrm{O}_{2}$ microsensor was placed $0.5 \mathrm{~cm}$ outside the edge of the measuring volume. The measuring volume was located 0.35 to $0.55 \mathrm{~m}$ above the sediment surface at $\sim 2$ times the seagrass canopy height. This measuring height guideline was adapted from atmospheric EC measurements over forest canopies to ensure that measurements were conducted within the constant flux layer (Burba 2013). This height is also consistent with guidelines determined in a recent modeling study (Rheuban \& Berg 2013) showing that $\sim 30 \mathrm{~cm}$ is needed to obtain a well-integrated flux signal over heterogeneous seagrass meadows. Data were recorded at $64 \mathrm{~Hz}$ for periods of at least $24 \mathrm{~h}$ to capture diel variations.

Supporting measurements were also recorded by the velocimeter and other instruments. From the velocity data, the current direction, mean current velocity, and significant wave height (or the mean height of the largest third of waves) were determined (Wiberg \& Sherwood 2008). Stable and temperaturecorrected $\mathrm{O}_{2}$ optodes (Hach or PME) were deployed at the EC measuring height and used to check and calibrate the $\mathrm{O}_{2}$ microsensor data. A salinity logger (Onset) was deployed at the EC measuring height to correct the optode $\mathrm{O}_{2}$ data for salinity variations. An $\mathrm{O}_{2}$ optode was also placed $10 \mathrm{~cm}$ above the sediment surface within the seagrass canopy during some deployments at RKB. Photosynthetically active radia- tion (PAR) was measured by 2 Odyssey PAR sensors (Dataflow Systems) at the EC measuring height that were calibrated to a LI-COR 193SA Spherical PAR Sensor, as described by Long et al. (2012).

The EC benthic $\mathrm{O}_{2}$ fluxes were determined across $0.25 \mathrm{~h}$ intervals from the time-averaged product of the instantaneous variations in the vertical velocity and the $\mathrm{O}_{2}$ concentration by the methods described in Berg et al. (2003) using the software package EddyFlux (P. Berg unpubl.). The instantaneous variations in the vertical velocity and $\mathrm{O}_{2}$ concentration were determined by Reynolds decomposition with the means determined from linear detrending over each $0.25 \mathrm{~h}$ interval. The velocity and $\mathrm{O}_{2}$ data were examined for anomalous variations due to particles and organisms contacting the sensors. Microsensor $\mathrm{O}_{2}$ data that varied from the stable optode data were discarded. The data were also examined for sensitivity to a 2-step rotation of the coordinate system's $x$-axis into the mean flow vector and the storage of $\mathrm{O}_{2}$ in the water column between the sediment surface and the measuring point (see Berg et al. 2003, Rheuban et al. 2014b). The differences between data treatments were compared by Kolmogorov-Smirnov (K-S) tests over $24 \mathrm{~h}$ data series at the $\alpha=0.05$ level. Differences between average site characteristics and flux rates were compared by ANOVAs at the $\alpha=0.05$ level. Linear regression analysis was used to examine the relationships between the fluxes and the individual measured parameters using binned and unbinned data, where the binned linear regressions were weighted by the standard error $( \pm \mathrm{SE})$ of each binned value (Motulsky \& Christopoulos 2004). Bin sizes were $200 \mu \mathrm{mol} \mathrm{m} \mathrm{m}^{-2} \mathrm{~s}^{-1}$ and $0.8 \mathrm{~cm} \mathrm{~s}^{-1}$ for PAR and velocity, respectively.

The daily rates of net ecosystem metabolism (NEM), gross primary production (GPP), and respiration were determined for continuous time series of $0.25 \mathrm{~h}$ flux data with the rates weighted by the hours of light and dark. Due to the inability to separate respiration and production in the observed net fluxes, the nighttime and daytime respiration rates were assumed to be the same (Falter et al. 2008, Hume et al. 2011). Therefore, the presented respiration and GPP rates are conservative estimates, as daytime respiration rates are likely higher than nighttime rates (Glud 2008, Long et al. 2013). For seagrasses specifically, a hysteresis in the $\mathrm{O}_{2}$ flux was observed that suggested increased rates of respiration in the afternoon, possibly due to highly labile photosynthates (Rheuban et al. 2014b). However, the NEM rates are calculated from the measured fluxes directly, and thus are not affected by this bias. 


\section{Treatment of eddy covariance data}

The EC fluxes were not significantly different when a 2-step rotation around the $z$ - and $y$-axis (to nullify the lateral and vertical velocities) was applied to each individual deployment as determined by K-S tests ( $\mathrm{p}>0.15$; data not shown). Therefore, none of the data were rotated. A correction for storage of $\mathrm{O}_{2}$ in the water between the sediment and the measuring height may be needed when large diurnal variations are seen in mean $\mathrm{O}_{2}$ concentration (Berg et al. 2003, Hume et al. 2011, Rheuban et al. 2014b). The use of large measuring heights (here 0.35 to $0.55 \mathrm{~m}$ ) increase the effect of this storage due to the larger volume of water below the measuring point. Derived $\mathrm{O}_{2}$ fluxes were found to be sensitive to this storage of $\mathrm{O}_{2}$ by K-S tests for 21 of the deployments at the $\alpha=$ 0.05 level. Therefore, the correction for storage was included in all flux calculations as outlined in detail by Rheuban et al. (2014b). While the storage correction affected our estimated rates of GPP and respiration significantly, it resulted in an average increase of only $1.3 \mathrm{mmol} \mathrm{O}_{2} \mathrm{~m}^{-2} \mathrm{~d}^{-1}$ in NEM rates. As expected, the storage-corrected NEM rates were not significantly different from the uncorrected rates (K-S test: $D=0.1333, \mathrm{p}=0.936$; ANVOA: $F_{1}=0.0102, \mathrm{p}=$ $0.9200)$.
The footprint, or the benthic area that contributes to the measured EC flux, is elliptically shaped and located upstream of the instrument (Berg et al. 2007). Berg et al. (2007) modeled the footprint characteristics for bare sediments that were exposed to unidirectional current flows and found a typical footprint to range from 10 to $100 \mathrm{~m}^{2}$. A conservative approximation based on this footprint modeling, and assuming a measuring height equal to the vertical distance between the seagrass canopy height and the EC measuring point, gave footprint lengths of 20 to $40 \mathrm{~m}$ for the seagrass sites in this study. While the current direction, and therefore the footprint orientation, was constantly changing, no correlation between current direction and the flux was found (data not shown), indicating a consistent and homogenous benthic surface. Consequently, the presented fluxes were assumed to represent the integrated, benthic metabolism of each seagrass site as a whole. Another first-order estimate, using the recent modeling results of Rheuban \& Berg (2013), revealed a delay between $\mathrm{O}_{2}$ released in the seagrass canopy and measurement at the EC measuring point of $<5$ min for most deployments. This result is supported by the apparently immediate response between measured light and derived EC fluxes shown in Fig. 2.
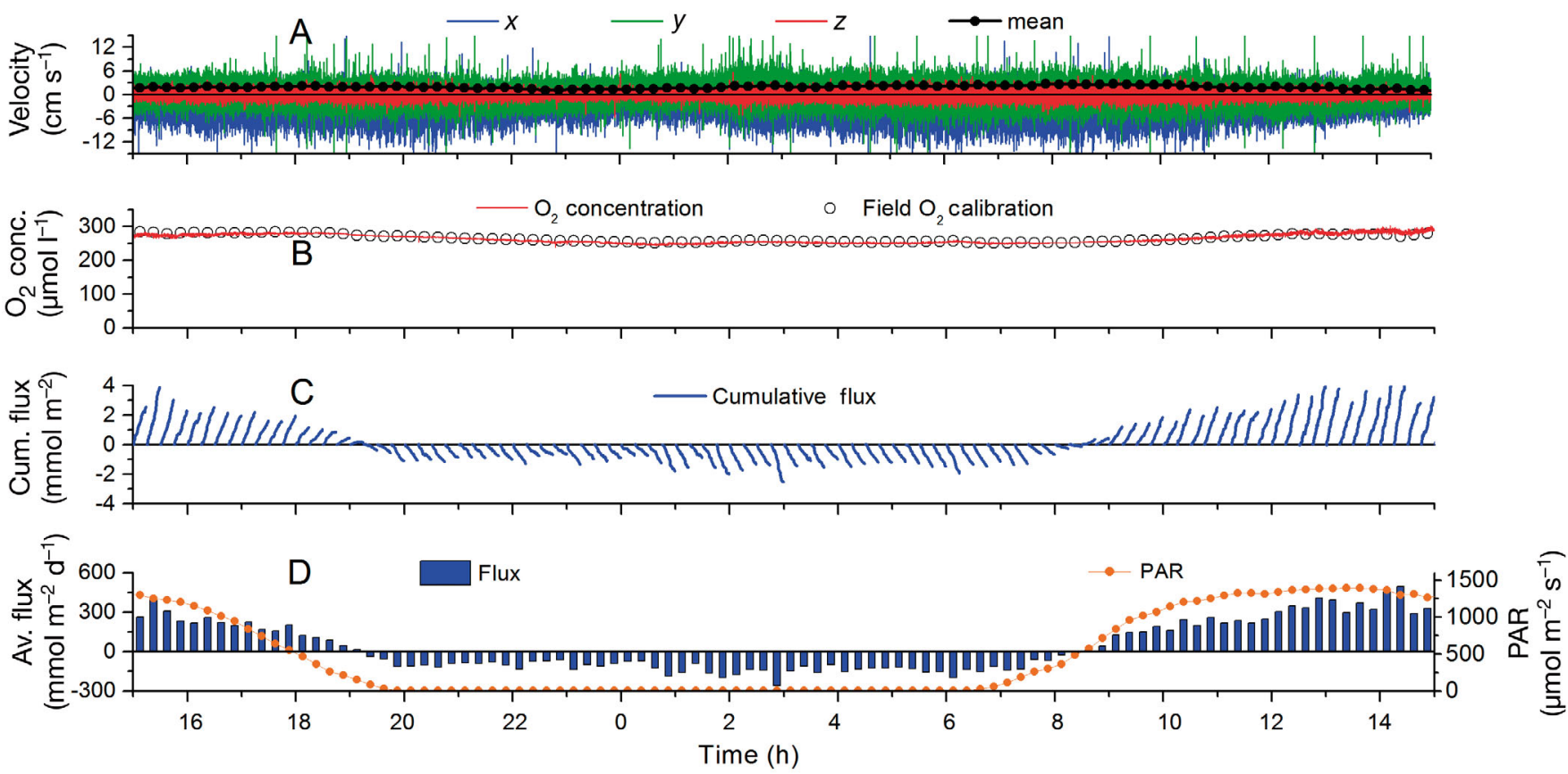

Fig. 2. Representative $24 \mathrm{~h}$ time series of eddy covariance (EC) data and fluxes for the offshore seagrass site GRS. The highresolution flux data $(0.25 \mathrm{~h})$ show a clear diurnal pattern with a tight coupling to irradiance. (A) $x, y$, and $z$ components of the velocity and the $0.25 \mathrm{~h}$ averaged mean current velocity measured by an acoustic Doppler velocimeter. (B) $\mathrm{O}_{2}$ concentration measured by the microsensor and the stable optode. (C) Cumulative fluxes, or the summation of the instantaneous fluxes over each $0.25 \mathrm{~h}$ period. (D) $0.25 \mathrm{~h}$ averaged fluxes and PAR values 


\section{Biomass addition technique}

Seagrass aboveground net primary production (NPP) was measured in 4 replicate quadrats $(0.1 \times$ $0.2 \mathrm{~m}$ ) randomly distributed within the EC area of measurement (Zieman 1989, Fourqurean et al. 2001). Each seagrass short shoot (ss) was marked by punching a hole at its base; it then grew for $\sim 2$ wk before sampling (adapted from Zieman 1974). The rates of aboveground NPP (measured as new biomass in $\mathrm{g}$ dry wt $\mathrm{ss}^{-1} \mathrm{~d}^{-1}$ ) were determined by collecting the aboveground seagrass material, separating newly grown biomass and old biomass, and determining dry weight. Shoot density and total aboveground biomass per square meter were also determined in the same quadrats. Subsamples of seagrass leaves were freeze-dried, ground, and their carbon content determined on a Carlo-Erba elemental analyzer to determine the $\mathrm{C}$ percentage of the newly added seagrass material. The ss density, newly grown biomass per ss, and the percentage $\mathrm{C}$ were used to calculate the NPP in $\mathrm{mmol} \mathrm{C} \mathrm{m}^{-2} \mathrm{~d}^{-1}$. As a first-order approximation to compare the NPP and EC rates, a simple 1:1 ratio was assumed between $\mathrm{O}_{2}$ and $\mathrm{C}$ metabolism (see Ziegler \& Benner 1998, Duarte et al. 2010).

\section{RESULTS}

\section{Site characteristics}

We confirmed the nutrient and biomass gradients across Florida Bay through increases in the biomass, total sedimentary phosphorus concentrations, porewater phosphorus, and organic matter from the isolated, northeast site, Duck, to the southwest site, RKB, adjacent to the Gulf of Mexico (Table 1, Fig. 1). The density of seagrasses in Florida Bay was the highest at BA (Table 1), but the seagrass leaf morphology was much shorter and thinner at this site, compared to that of RKB (Fig. 1). This also was evident from the amount of biomass per ss of $0.24 \pm 0.04$, $0.12 \pm 0.02$, and $0.06 \pm 0.02 \mathrm{~g}$ dry wt $\mathrm{ss}^{-1}$ for RKB, BA, and Duck, respectively ( $\pm \mathrm{SE}$ ). The offshore seagrass site, GRS, had a similar morphology to RKB (0.26 \pm $0.06 \mathrm{~g} \mathrm{dry} \mathrm{wt} \mathrm{ss}^{-1}$ ) and had the largest biomass of 193 $\pm 39 \mathrm{~g}$ dry wt $\mathrm{m}^{-2}( \pm \mathrm{SE}, \mathrm{n}=4)($ Table 1$)$.

\section{Seagrass meadow metabolic rates}

A total of 53 EC deployments were performed across all 4 sites. Due to frequent $\mathrm{O}_{2}$ microsensor breakage, these deployments resulted in 32 complete $24 \mathrm{~h}$ time series. Fig. 2 shows one of the $24 \mathrm{~h}$ data sets, including the $0.25 \mathrm{~h}$ extracted fluxes, from the offshore GRS site. The clear linear trends in the cumulative fluxes, or the integration of the instantaneous fluxes across each $0.25 \mathrm{~h}$ period (Fig. 2C), indicate a consistent, strong eddy flux signal in the highfrequency data. The diel changes and high temporal resolution of the integrated $0.25 \mathrm{~h}$ fluxes are evident in Fig. 2D.

Integrating the EC fluxes across each $24 \mathrm{~h}$ period revealed rates of GPP that exceeded respiration to produce an average positive NEM for all sites (Fig. 3). The average daily rates of GPP and respiration varied significantly across the bay sites (Fig. 3, Table 2). In Florida Bay, the highest rates of GPP, respiration, and NEM were at RKB and the lowest rates were at Duck (Table 2), which was consistent with the gradients of seagrass biomass, sediment phosphorus, porewater phosphate, and sediment organic matter (Table 1). The net trophic status during the summer was determined by comparing the relationship between the daily rates of GPP and respiration with a meta-

Table 1. Site characteristics and ANOVAs across sites $( \pm \mathrm{SE})$. ANOVA $F$ and p values are across only the Florida Bay sites of RKB, BA, and Duck. Shading indicates data not included in ANOVAs. Superscript letters indicate significant differences between the individual sites determined by Tukey post-tests (no letters indicate no differences). ss: seagrass short shoot; ND: no data

\begin{tabular}{|c|c|c|c|c|c|c|c|c|c|}
\hline Site & $\begin{array}{c}\text { Above- } \\
\text { ground } \\
\text { biomass } \\
\text { (g dry wt } \mathrm{m}^{-2} \text { ) }\end{array}$ & $\begin{array}{l}\text { Short } \\
\text { shoot } \\
\text { density } \\
\left(\mathrm{ss} \mathrm{m}^{-2}\right)\end{array}$ & $\begin{array}{l}\text { Sediment } \\
\text { organic } \\
\text { matter } \\
(\%)\end{array}$ & $\begin{array}{c}\text { Sediment } \\
\text { total } \\
\text { phosphorus } \\
\left.(\mu \mathrm{mol} \mathrm{g})^{-1}\right)\end{array}$ & $\begin{array}{c}\text { Porewater } \\
\text { phosphate } \\
\left(\mu \mathrm{mol} \mathrm{l}^{-1}\right)\end{array}$ & $\begin{array}{c}\text { Water } \\
\text { column } \\
\text { temperature } \\
\left({ }^{\circ} \mathrm{C}\right)\end{array}$ & $\begin{array}{l}\text { Mean } \\
\text { current } \\
\text { velocity } \\
\left(\mathrm{cm} \mathrm{s}^{-1}\right)\end{array}$ & $\begin{array}{l}\text { Signifi- } \\
\text { cant wave } \\
\text { height } \\
(\mathrm{cm})\end{array}$ & Salinity \\
\hline GRS & $193 \pm 39$ & $755 \pm 65$ & ND & ND & ND & $30.6 \pm 0.1$ & $2.6 \pm 0.1$ & $16.4 \pm 0.3$ & ND \\
\hline RKB & $136 \pm 17^{a}$ & $565 \pm 65^{a, b}$ & $9.2 \pm 0.5^{\mathrm{a}}$ & $3.0 \pm 0.2^{\mathrm{a}}$ & $0.27 \pm 0.04^{\mathrm{a}}$ & $30.7 \pm 0.1^{\mathrm{a}}$ & $4.2 \pm 0.2^{\mathrm{a}}$ & $2.8 \pm 0.1$ & $36.4 \pm 2.0^{\mathrm{a}}$ \\
\hline BA & $75 \pm 12^{a, b}$ & $642 \pm 42^{\mathrm{b}}$ & $6.8 \pm 0.3^{\mathrm{b}}$ & $1.4 \pm 0.1^{b}$ & $0.19 \pm 0.02^{a, b}$ & $29.1 \pm 0.1^{\mathrm{b}}$ & $1.4 \pm 0.0^{\mathrm{b}}$ & $3.1 \pm 0.1$ & $30.6 \pm 1.0^{\mathrm{b}}$ \\
\hline Duck & $24 \pm 6^{b}$ & $406 \pm 41^{\mathrm{a}}$ & $4.1 \pm 0.3^{\mathrm{c}}$ & $0.8 \pm 0.1^{\mathrm{c}}$ & $0.07 \pm 0.06^{\mathrm{b}}$ & $31.2 \pm 0.1^{\mathrm{c}}$ & $2.0 \pm 0.1^{\mathrm{c}}$ & $3.1 \pm 0.1$ & $24.5 \pm 1.2^{\mathrm{c}}$ \\
\hline$F_{2}$ & 15.14 & 5.68 & 51.80 & 76.19 & 5.03 & 135.01 & 211.87 & 2.63 & 142.05 \\
\hline $\mathrm{p}$ & 0.0019 & 0.0183 & $<0.0001$ & $<0.0001$ & 0.0212 & $<0.0001$ & $<0.0001$ & 0.073 & $<0.0001$ \\
\hline
\end{tabular}




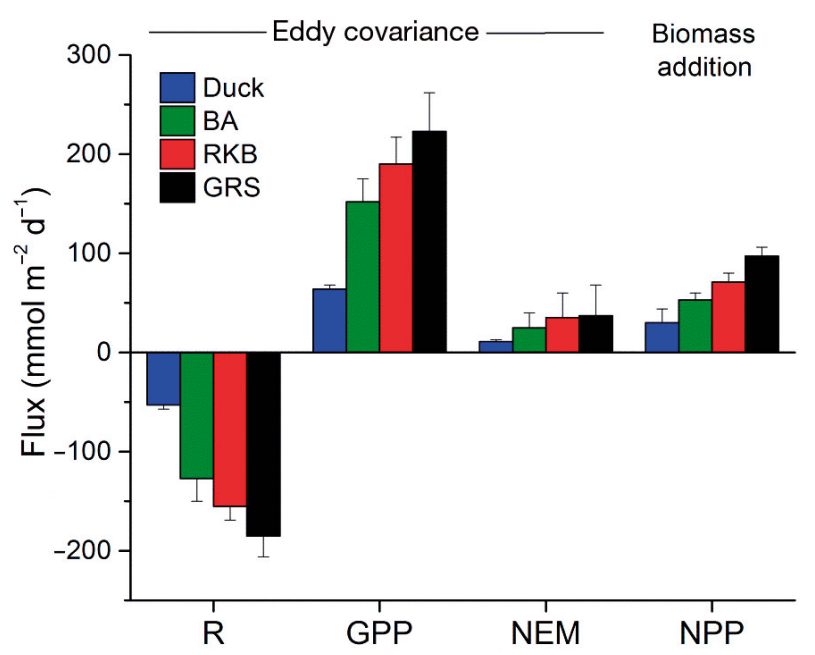

Fig. 3. Respiration (R), gross primary production (GPP), and net ecosystem metabolism (NEM) determined from the high temporal resolution EC data across southern Florida. Seagrass aboveground net primary production (NPP) was determined over $2 \mathrm{wk}$ by the marking technique. Flux units are oxygen for EC data and carbon for the marking technique. Error bars represent SE. EC error estimates include the natural, daily variation in the flux due to changes in environmental conditions such as irradiance and flow. These natural variations are not resolved with the biomass addition technique and therefore the error estimates for this approach

largely represent vari-ations between individual shoots

bolically balanced relationship (see Hume et al. 2011, Rheuban et al 2014a,b). At each site the relationship between GPP and respiration had a slope that indicated net autotrophy, with slopes of $-0.94,-0.47$, -0.22 , and -0.13 for Duck, BA, RKB, and GRS, respectively. These linear relationships were then compared against that of the $-1: 1$ metabolically balanced relationship using an F-test (Motulsky \& Christopoulos $2004)$ with Duck $(F=7.2548, \mathrm{p}=0.0197)$, BA $(F=$ $7.8772, \mathrm{p}=0.0105), \operatorname{RKB}(F=6.8513, \mathrm{p}=0.0156)$, and GRS $(F=7.2932, \mathrm{p}=0.0068)$ all being significantly different at the $\alpha=0.05$ level, indicating net autotrophy at all sites.

The seagrass aboveground NPP rates from the biomass addition technique integrated over the short-term variations in community NEM that were observed with the EC technique. The NPP rates decreased across Florida Bay, with rates of $71 \pm 9,53 \pm 7$, and $30 \pm 14 \mathrm{mmol} \mathrm{C} \mathrm{m}^{-2} \mathrm{~d}^{-1}( \pm \mathrm{SE}, \mathrm{n}$ = 4), for RKB, BA, and Duck, respectively (Fig. 3) (ANOVA: $\left.F_{2}=2.6289, \mathrm{p}=0.1326\right)$. In Florida Bay, these NPP rates
Table 2. EC respiration (R), gross primary production (GPP), and net ecosystem metabolism (NEM) rates $( \pm \mathrm{SE})$. ANOVA $F$ and $p$ values are across only the Florida Bay sites of RKB, BA, and Duck. Superscript letters indicate significant differences between the individual sites determined by Tukey post-tests (no letters indicate no differences)

\begin{tabular}{|c|c|c|c|c|}
\hline Site & $\mathrm{R}$ & $\begin{array}{c}\text { GPP } \\
\left.\operatorname{mol~O} \mathrm{m}^{-2} \mathrm{~d}^{-1}\right)\end{array}$ & NEM & $\mathrm{n}$ \\
\hline GRS & $-185 \pm 21$ & $223 \pm 49$ & $37 \pm 31$ & 5 \\
\hline RKB & $-155 \pm 14^{\mathrm{a}}$ & $190 \pm 27^{\mathrm{a}}$ & $35 \pm 25$ & 7 \\
\hline BA & $-127 \pm 23^{\mathrm{a}}$ & $151 \pm 23^{b}$ & $25 \pm 15$ & 8 \\
\hline Duck & $-52 \pm 4^{\mathrm{b}}$ & $68 \pm 6^{\mathrm{c}}$ & $11 \pm 2$ & 12 \\
\hline$F_{2}$ & 17.1601 & 14.4724 & 0.4547 & \\
\hline $\mathrm{p}$ & $<0.0001$ & $<0.0001$ & 0.6398 & \\
\hline
\end{tabular}

were consistently higher $(2.0,2.1$, and 2.7 times higher for RKB, BA, and Duck, respectively) than the EC NEM rates across the sites and followed the same decreasing productivity trend with the decreasing phosphorus gradient. The NPP rate at the GRS site of $97 \pm 9 \mathrm{mmol} \mathrm{C} \mathrm{m}^{-2} \mathrm{~d}^{-1}( \pm \mathrm{SE}, \mathrm{n}=4)$ was also 2.6 times greater than the NEM determined by EC (Fig. 3).

\section{Dynamics of seagrass meadow metabolism}

An $8 \mathrm{~h}$ data set from a variably cloudy day illustrates the metabolic response of the seagrass meadow to changes in irradiance (Fig. 4A). The photosynthesis to irradiance (P-I) relationship for all GRS data (Fig. 4B) exhibited a linear correlation under all light conditions and did not show a typical maximum production rate or any evidence of light saturation, but instead steadily increased with increasing irradiance (Fig. 4B, Table 3). The P-I relationship had a light compensation point $\left(I_{C}\right)$, or the irradiance value where respiration equals production, of $339 \mu \mathrm{mol}$ photons $\mathrm{m}^{-2} \mathrm{~s}^{-1}$ and a slope, indicating the efficiency

Table 3. P-I relationship parameters and statistics $( \pm \mathrm{SE})$. ANOVA $F$ and p values are across only the Florida Bay sites of RKB, BA, and Duck. Superscript letters indicate significant differences between the individual sites determined by Tukey post-tests (no letters indicate no differences)

\begin{tabular}{|c|c|c|c|c|c|c|c|}
\hline \multirow[t]{2}{*}{ Site } & \multirow[t]{2}{*}{ Slope } & \multirow{2}{*}{$\begin{array}{c}I_{\mathrm{c}} \\
(\mu \mathrm{mol} \\
\left.\mathrm{m}^{-2} \mathrm{~s}^{-1}\right)\end{array}$} & \multirow{2}{*}{$\begin{array}{l}\text { Slope:biomass } \\
\text { (normalized } \\
\text { ratio) }\end{array}$} & \multicolumn{2}{|c|}{ _ Binned __ } & \multicolumn{2}{|c|}{ —Unbinned - } \\
\hline & & & & $\mathrm{r}^{2}$ & $\mathrm{p}$ & $r^{2}$ & $\mathrm{p}$ \\
\hline GRS & $0.52 \pm 0.02$ & $339 \pm 21$ & $0.45 \pm 0.09$ & 0.99 & $\mathrm{p}<0.0001$ & 0.76 & $p<0.0001$ \\
\hline RKB & $0.81 \pm 0.06^{\mathrm{a}}$ & $200 \pm 16^{a}$ & $1.01 \pm 0.14$ & 0.99 & $p<0.0001$ & 0.75 & $p<0.0001$ \\
\hline $\mathrm{BA}$ & $0.45 \pm 0.02^{\mathrm{b}}$ & $239 \pm 22^{\mathrm{a}}$ & $1.00 \pm 0.17$ & 0.97 & $p<0.0001$ & 0.68 & $p<0.0001$ \\
\hline Duck & $0.15 \pm 0.01^{\mathrm{c}}$ & $314 \pm 29^{b}$ & $0.95 \pm 0.25$ & 0.95 & $\mathrm{p}<0.0001$ & 0.55 & $\mathrm{p}<0.0001$ \\
\hline$F_{2}$ & 15.14 & 5.9414 & 0.307 & & & & \\
\hline $\mathrm{p}$ & 0.0019 & 0.0111 & 0.9698 & & & & \\
\hline
\end{tabular}



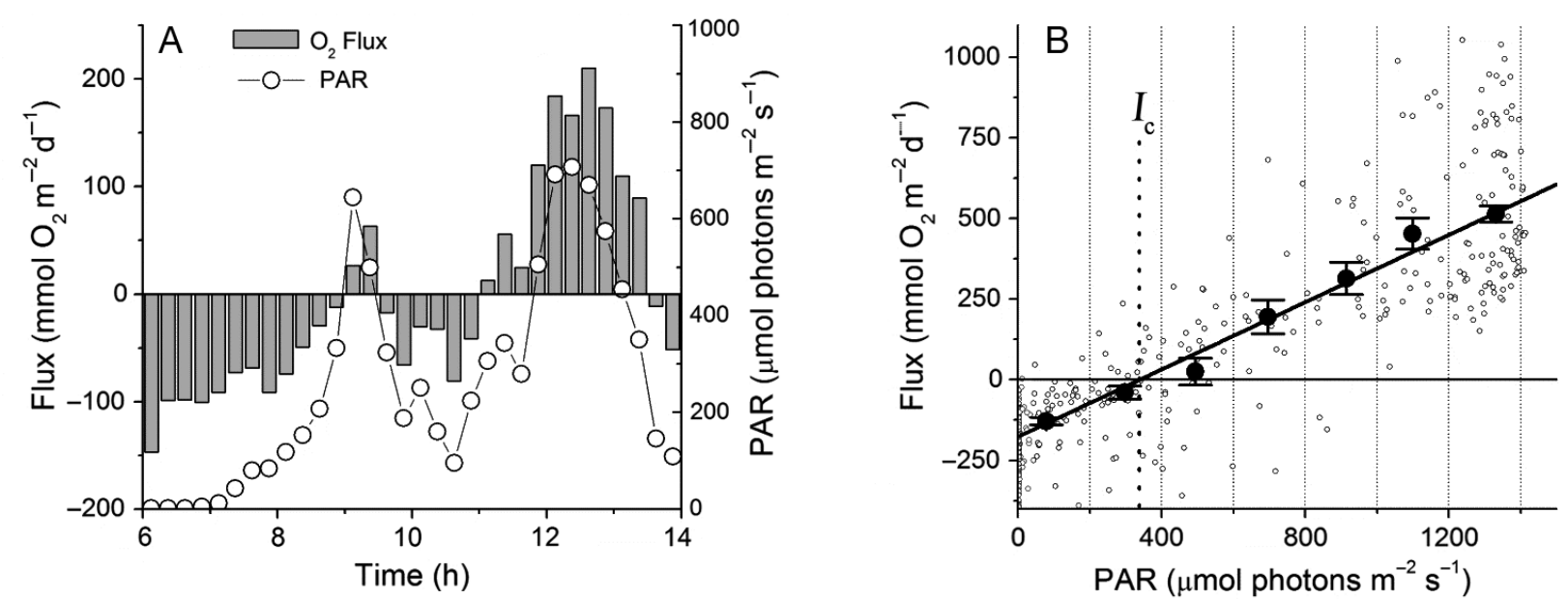

Fig. 4. (A) Tight coupling between PAR and the $\mathrm{O}_{2}$ flux over an $8 \mathrm{~h}$ period at the offshore GRS site during a partly cloudy day. (B) Overall relationship between PAR and the flux for all offshore GRS daytime data, which shows a linear P-I relationship. $I_{C}$ indicates the amount of PAR needed to produce a net flux of 0 , representing a balance between respiration and production. Individual fluxes were bin averaged by 200 PAR where the error bars represent SE. The line is a linear regression, weighted by the SE of each binned average

of light utilization, of 0.52 (Table 3). Similar to the offshore GRS site, the P-I relationships for all data at each of the bay sites had linear correlations without any indication of light saturation (Fig. 5, Table 3). The efficiency of light utilization by seagrass meadows was apparent from the P-I relationship slopes, where RKB had the steepest (0.81), BA had an intermediate slope (0.45), and Duck had the smallest slope (0.16) (Table 3). A 1:1 relationship between the slope of the P-I relationships and the seagrass bio-

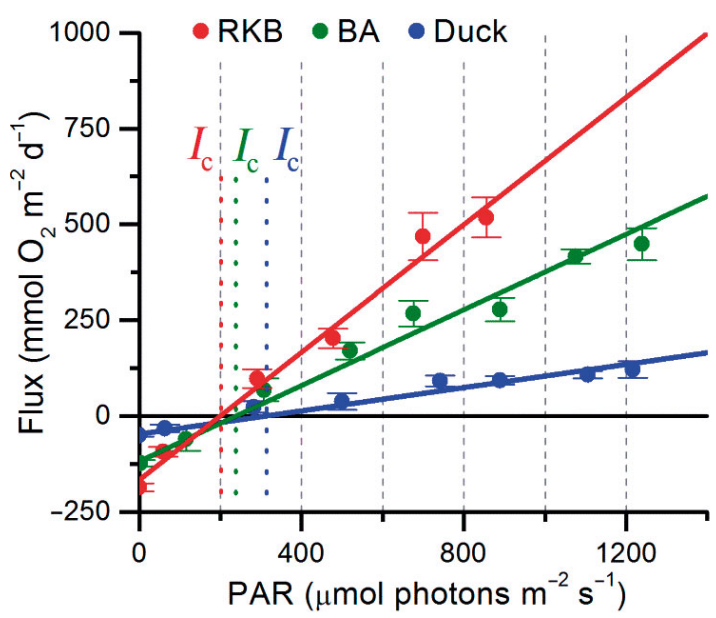

Fig. 5. P-I relationships for the Florida Bay sites, where the steepest slope was found at the highest biomass site of RKB. Individual fluxes were bin-averaged by $200 \mu \mathrm{mol}$ photons $\mathrm{m}^{-2} \mathrm{~s}^{-1}$ where the error bars represent SE. Lines are linear regressions, weighted by the SE of each binned average. $I_{\mathrm{c}}$ is represented by the dashed lines and indicates the PAR flux rate needed to produce a balance between production and respiration. See Table 2 for statistics mass was found at the bay sites (Table 3 ). The $I_{\mathrm{C}}$ were 200, 239, and $314 \mu \mathrm{mol}$ photons $\mathrm{m}^{-2} \mathrm{~s}^{-1}$ for RKB, BA, and Duck, respectively (Table 3 ).

An $8 \mathrm{~h}$ segment of nighttime data (Fig. 6A) shows the tight coupling between respiration and current velocity. The nighttime fluxes were negatively correlated with the mean current velocity for all GRS data (Fig. 6B) (binned data: $\mathrm{p}=0.0022, \mathrm{r}^{2}=0.96$; unbinned data: $p=0.0001, r^{2}=0.18$ ). The nighttime fluxes were also negatively correlated with the mean flow velocity at RKB (data not shown; binned data: $\mathrm{p}=0.0174$, $\mathrm{r}^{2}=0.88$; unbinned data: $\left.\mathrm{p}=0.0007, \mathrm{r}^{2}=0.14\right)$ and Duck (binned data: $\mathrm{p}=0.0197, \mathrm{r}^{2}=0.87$; unbinned data: $p=0.0002, r^{2}=0.10$ ) but not at BA, the site with the lowest current velocity (unbinned data: $p=$ 0.6938). At the offshore GRS site, the covariance of flow and irradiance during the day prevented the determination of flow effects on daytime flux rates. At the bay sites, there was no covariance between irradiance and flow. However, no significant correlations were found between the daytime flux and flow.

The offshore GRS site had the largest significant wave heights (Table 1) and the flux was negatively correlated to this variable during both the day (binned data: $\mathrm{p}=0.0276, \mathrm{r}^{2}=0.885$; unbinned data: $\mathrm{p}=0.0295$, $\mathrm{r}^{2}=0.09$ ) and night (binned data: $\mathrm{p}=0.03292, \mathrm{r}^{2}=$ 0.825 ; unbinned data: $\mathrm{p}<0.0001, \mathrm{r}^{2}=0.14$ ). None of the bay sites had significant correlations between the flux and waves during the day or night, likely due to the small wave heights (Table 1). There were no consistent trends for any sites between the flux and temperature (varying from 27.7 to $33.3^{\circ} \mathrm{C}$ ), salinity (Table 1), or current direction during the day or night. 

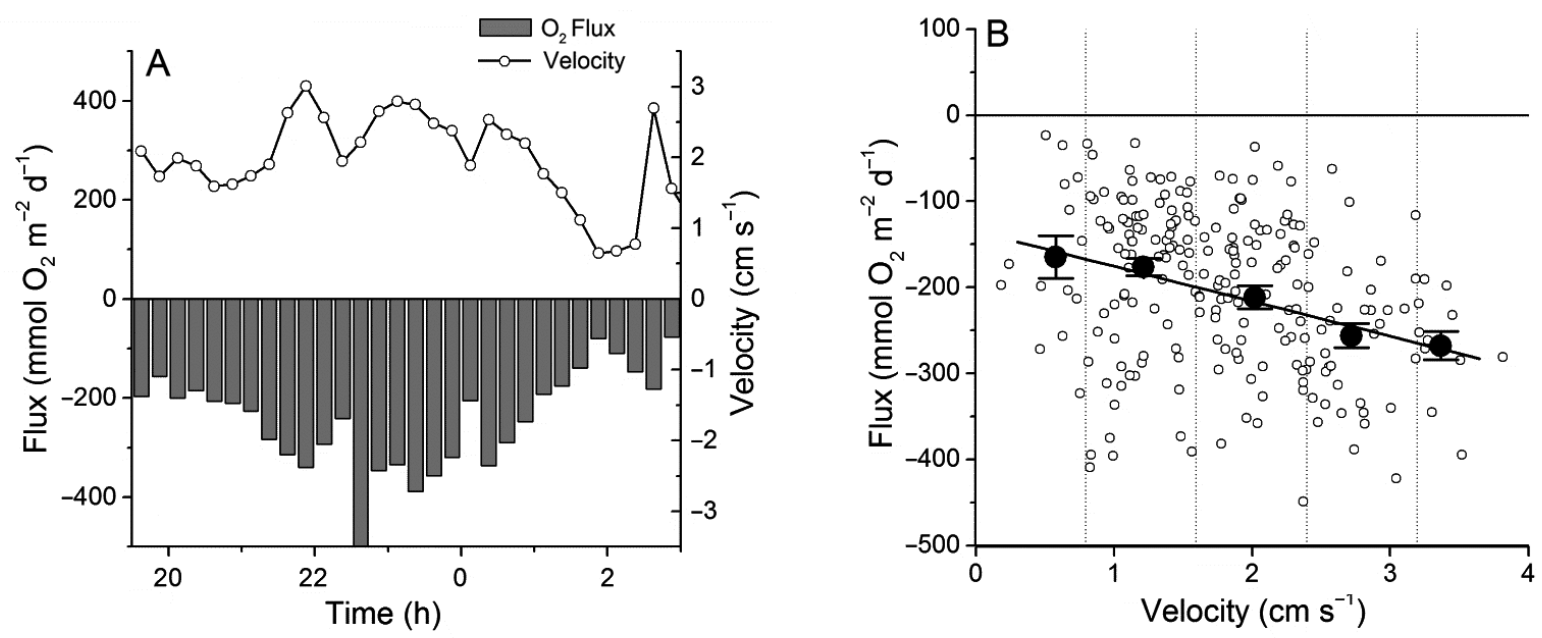

Fig. 6. (A) Stimulation of respiration by flow velocity over an $8 \mathrm{~h}$ nighttime period at the offshore GRS site. (B) Nighttime relationship between the flux and velocity across all offshore GRS nighttime data. Individual fluxes were averaged in $0.8 \mathrm{~cm} \mathrm{~s}$ bins where the error bars represent SE. The line is a linear regression, which is weighted by the SE of each binned average

For each site, all of the $0.25 \mathrm{~h}$ fluxes and PAR data were averaged hourly to produce $\mathrm{O}_{2}$ fluxes by the hour of day (Fig. 7). The high temporal resolution EC data shows the large amount of variability that occurred between different days and sites. The offshore GRS site had the largest range of hourly day and night fluxes (1053 and $-549 \mathrm{mmol} \mathrm{O}_{2} \mathrm{~m}^{-2} \mathrm{~d}^{-1}$, respectively) (Fig. 7A) and PAR levels (1410 $\mu \mathrm{mol}$ photons $\mathrm{m}^{-2} \mathrm{~s}^{-1}$ ) (Fig. 7E). Despite the lowest average irradiances at RKB (Fig. 7F), the largest average $\mathrm{O}_{2}$ fluxes in Florida Bay were found at this site (Fig. 7B), while Duck had the highest irradiances but the low- est fluxes (Fig. 7D). Daily NEM values ranged from 1 to $21,-27$ to $80,-51$ to 120 , and -59 to $173 \mathrm{mmol} \mathrm{O}_{2}$ $\mathrm{m}^{-2} \mathrm{~d}^{-1}$ at Duck, BA, RKB, and GRS, respectively. The daily GPP rates across all sites (Fig. 8) further show the day-to-day variability within each site and the relationship to the daily irradiance.

The measurement of $\mathrm{O}_{2}$ above the sediment, but within the dense seagrass canopy, at RKB revealed that $\mathrm{O}_{2}$ builds up during the day (Fig. 9A) and becomes depleted during the night (Fig. 9B) during periods with minimal vertical mixing due to low-flow conditions.
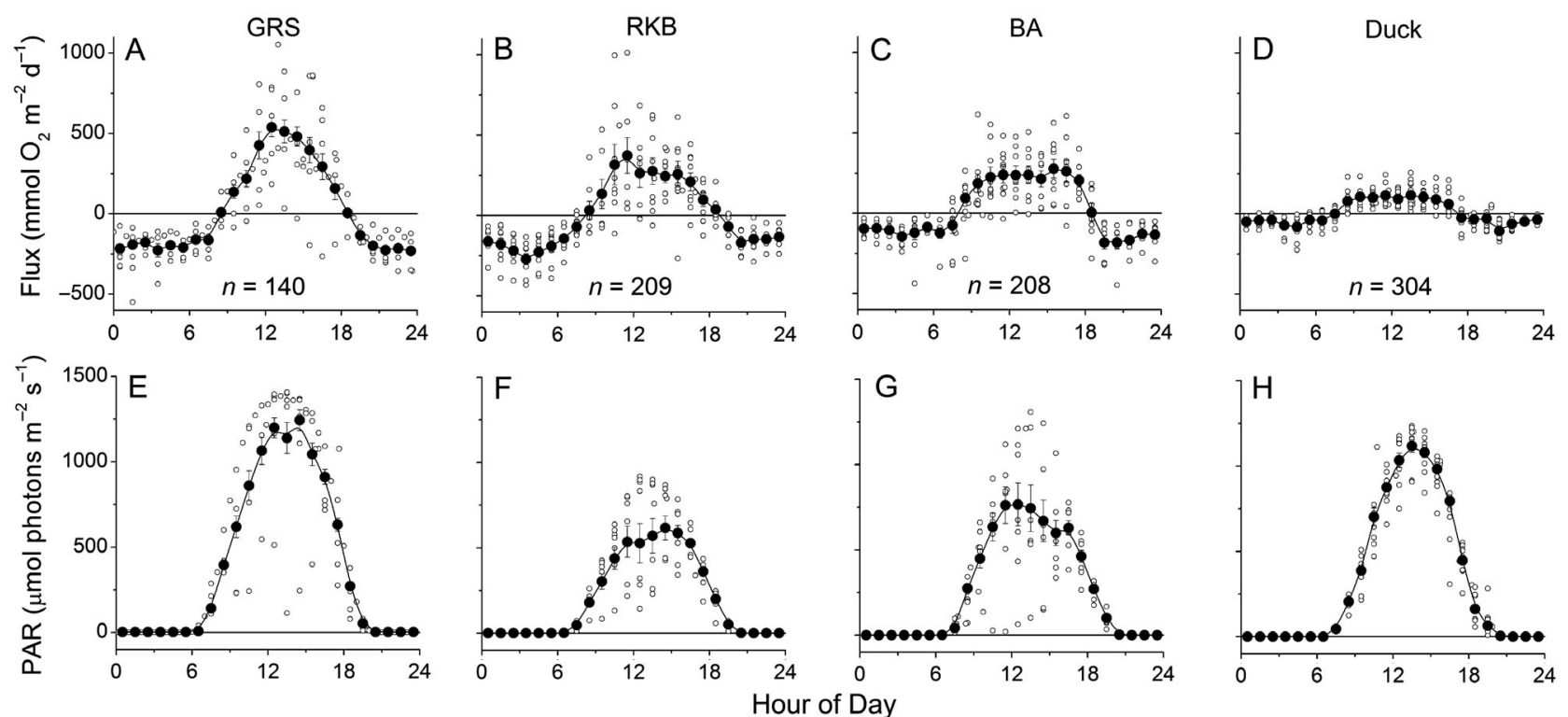

Fig. 7. (A-D) All EC $\mathrm{O}_{2}$ flux data and (E-H) PAR data for each site by the hour of day. (०) Individual hourly fluxes; (•) fluxes bin-averaged by hour of day for the different deployments. The error bars represent SE 

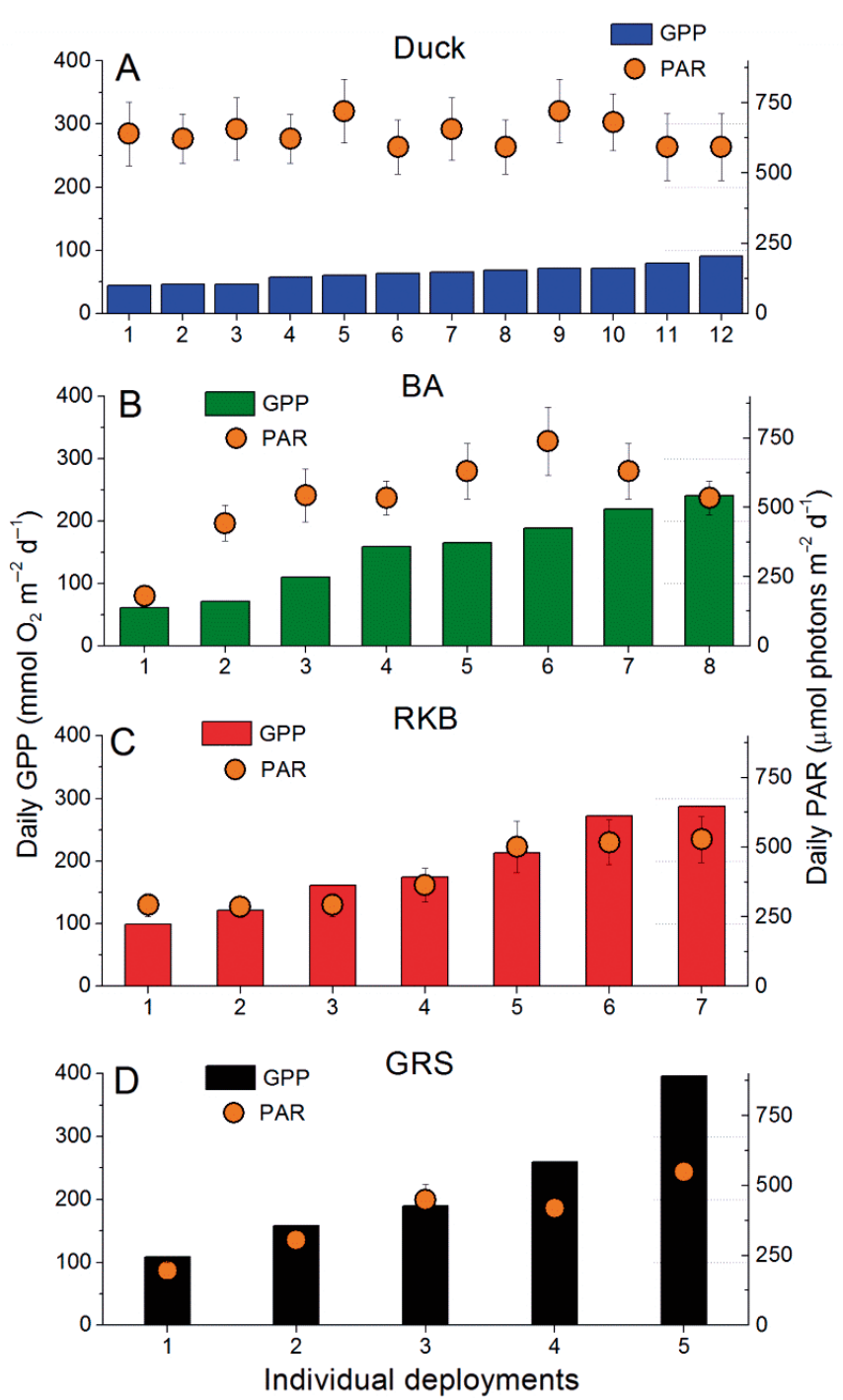

Fig. 8. (A-D) Daily GPP and PAR during each deployment across the 4 sites. The individual deployments at each site are sorted by increasing GPP rates. The error bars are SE

\section{DISCUSSION}

\section{Seagrass meadow metabolic rates}

The net metabolic measurements from the EC technique during the summer indicated that the seagrass ecosystems were on average net autotrophic at both the offshore GRS site ( $37 \mathrm{mmol} \mathrm{O}_{2} \mathrm{~m}^{-2} \mathrm{~d}^{-1}$ ) and all the Florida Bay sites (on average $24 \mathrm{mmol} \mathrm{O}_{2} \mathrm{~m}^{-2} \mathrm{~d}^{-1}$ ). This is consistent with most metabolic measurements in tropical seagrass meadows that quantify them as a significant source of annual primary production (Gattuso et al. 1998, Duarte et al. 2010, Fourqurean et al. 2012) and comparable with the global average for all seagrass systems reported in Duarte et al. (2010) of

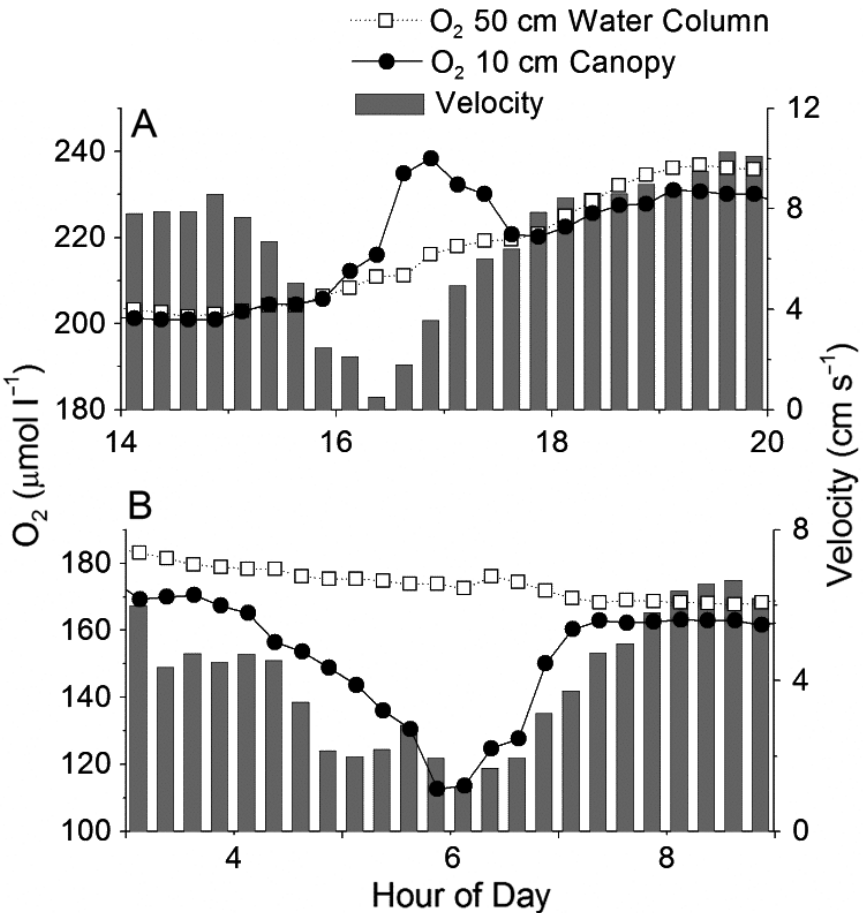

Fig. 9. Variations in the $\mathrm{O}_{2}$ concentration due to flow velocity above the seagrass canopy and within the seagrass canopy during (A) day and (B) night at RKB

$27 \mathrm{mmol} \mathrm{C} \mathrm{m}^{-2} \mathrm{~d}^{-1}$ annually, when a 1:1 relationship is assumed between $\mathrm{O}_{2}$ and $\mathrm{C}$ (see Ziegler \& Benner 1998, Duarte et al. 2010). The consistently $>2$-fold difference between the EC NEM rates and the seagrass biomass addition NPP rates were expected, as the NPP rates only include the aboveground component of seagrass metabolism and seagrass belowground respiration (Fig. 3). Therefore, the combination of other producers, consumers, and belowground seagrass growth was net heterotrophic based on the differences between the NPP and NEM rates.

The average summertime EC NEM rates for individual sites within Florida Bay (11 to $35 \mathrm{mmol} \mathrm{O}_{2} \mathrm{~m}^{-2}$ $\mathrm{d}^{-1}$ ) were also consistent with chamber measurements by Yarbro \& Carlson (2008) in Florida Bay that ranged from -6 to $50 \mathrm{mmol} \mathrm{O}_{2} \mathrm{~m}^{-2} \mathrm{~d}^{-1}$ during summer. However, the range of daily NEM values presented here (-51 to $120 \mathrm{mmol} \mathrm{O}_{2} \mathrm{~m}^{-2} \mathrm{~d}^{-1}$ ) was substantially larger than chamber rates, suggesting that flow effects (which are excluded in chamber measurements) and sampling under variable in situ conditions (e.g. flow and light) are important in determining accurate rates of metabolism. Further, Yarbro \& Carlson (2008) stated that unfavorable weather conditions prevented successful chamber deployments, which likely created the order of magnitude difference between EC and chamber measurements 
under low-productivity conditions (e.g. -51 versus $-6 \mathrm{mmol} \mathrm{O}_{2} \mathrm{~m}^{-2} \mathrm{~d}^{-1}$ ). Evaluating metabolism under low irradiance or low productivity conditions is important in seagrass ecosystems because shading experiments show that seagrasses rely on rhizome carbohydrates to maintain growth at reduced irradiances (Mackey et al. 2007, Lavery et al. 2009, Gacia et al. 2012). This suggests that any sampling bias toward high-light conditions may overestimate the NEM due to both the reduction in photosynthesis and the high rates of carbohydrate respiration by seagrasses during low-irradiance periods. Therefore, the ability of EC to sample across a wider range of field conditions increases the variability of EC NEM rates, and likely results in a more accurate characterization of metabolism under in situ conditions.

The temporal variability of EC fluxes (Figs. 4 \& 6-8) further highlights the need to sample across adequate timescales to obtain accurate metabolic rates. Compared to traditional methods of measuring metabolism, such as chamber measurements, biomass addition techniques, and core incubations, the in situ EC sampling over numerous diel cycles can resolve these variations. However, the presence of these in situ variations also suggests that the period of measurement presented here (5 to $12 \mathrm{~d}$ at each site; Fig. 8) may not in some cases be long enough to determine an accurate seasonal estimate of NEM and that shorter timescale measurements likely introduce significant errors.

\section{Dynamics of seagrass meadow metabolism}

At all 4 sites the daytime fluxes, when measured in situ on an ecosystem scale, increased linearly with irradiance and did not approach a saturating condition even at high summer irradiances (Figs. 4B \& 5). The P-I relationships for seagrass ecosystems are typically reported as reaching saturating conditions (see review by Lee et al. 2007), but in situ ecosystemscale measurements, where all autotrophs are included, may produce an efficient use of the incident irradiance that prevents saturation (Binzer et al. 2006, Sand-Jensen et al. 2007, Rheuban et al. 2014a). Thalassia testudinum canopies can have a leaf area index of up to $18 \mathrm{~m}^{2} \mathrm{~m}^{-2}$ (Gessner 1971), which is equivalent to the highest values reported for terrestrial ecosystems (tree plantations, Asner et al. 2003). This large area is generally thought to be an adaptation to capture more light and to compensate for the shading effects of epiphytes (Dawes 1998). While the upper portions of the canopy may become saturated with light, the lower portions are shaded and likely undersaturated (Durako \& Kunzelman 2002, Cayabyab \& Enriquez 2007, Mackey et al. 2007). The complex structure of seagrass canopies creates high amounts of diffuse light and the movement of the flexible blades periodically exposes different parts of the canopy to light, both of which enhance the light capture by the canopy (Enriquez et al. 2002, Enriquez \& Pantoja-Reyes 2005). Further, seagrass leaf morphology is plastic, and alterations in leaf size and shape can increase light capture and growth (Enriquez \& Pantoja-Reyes 2005, Cayabyab \& Enriquez 2007). In contrast to a review by Lee et al. (2007) that reported an average and maximum saturating irradiance for $T$. testudinum of 253 and $438 \mu \mathrm{mol}$ photons $\mathrm{m}^{-2} \mathrm{~s}^{-1}$, respectively, the linear and non-saturating conditions observed here using the EC technique at relatively high underwater irradiances (up to $1400 \mu \mathrm{mol}$ photons $\mathrm{m}^{-2} \mathrm{~s}^{-1}$ ) more likely represent the true ecosystem-scale photosynthetic response to light.

The nighttime respiration rates were likely facilitated by local hydrodynamics, which flush sediments and enhance the exchange of gases, solutes, and organic C (Precht \& Huettel 2003, Reimers et al. 2004, Hume et al. 2011). The correlation between flow and $\mathrm{O}_{2}$ exchange is likely due to the combined effects of the flushing of sediment porewater and seagrass canopy, the facilitation of respiration through nutrient and waste transfer, and the reduction in thickness of the diffusive boundary layer around individual flora and fauna (Rheuban et al. 2014a). A strong correlation between flow velocity and respiration rates was observed during the night at the offshore GRS site (Fig. 6), likely due to the high permeability of the coarse offshore sediments and the high biomass density. The correlation between flow and nighttime respiration was also observed at the 2 highest velocity sites in Florida Bay (RKB and Duck) (Table 1), but produced weaker correlations compared to the offshore site, probably due to the less-permeable carbonate muds and lower biomass in Florida Bay. The high respiration rates in the coarse offshore sediments explains the higher $I_{\mathrm{c}}$ and lower slope in the P-I relationship at the GRS site compared to the similar RKB site in Florida Bay (Table 2).

The lack of exchange during low-flow conditions between the seagrass canopy and the overlying water was evident from the build-up or depletion of $\mathrm{O}_{2}$ within the canopy (Fig. 9). This suggests that some of the correlation between the $\mathrm{O}_{2}$ flux and flow is due to the flushing of the canopy, as well as the 
sediment, and is a source of some of the highfrequency variability in the measured flux rates. Further, the depletion of $\mathrm{O}_{2}$ within the canopy suggests that significant hypoxic stress may occur for heterotrophic organisms residing there during periods of low flow.

Numerous studies have shown the effect of flow on productivity, which alters gas exchange by changing the thickness of the diffusive boundary layer (Fonseca \& Kenworthy 1987, Finelli et al. 2007, Mass et al. 2010). The covariance between the flow velocity (by tides) and irradiance made the separation of their individual effects on daytime production difficult at the offshore GRS site. At the bay sites (where flow and irradiance did not co-vary), no significant increase in the daytime fluxes was observed with increasing flow velocity, possibly because any increases in production due to flow velocity were balanced by flow-facilitated respiration (e.g. Fig. 6). Another factor that likely reduced photosynthesis under high, unidirectional flow conditions was the flowinduced bending of seagrass blades that increased the self-shading of the seagrass canopy (Fonseca \& Kenworthy 1987). This bending significantly reduces the below-canopy flow and likely limits exchange (Fonseca \& Fisher 1986, Koch \& Gust 1999, Nepf 2012). However, the covariance of increased shading and reduced exchange limits the separation of their effects through $\mathrm{O}_{2}$ concentrations (e.g. Fig. 9A).

In contrast to the effects of unidirectional flows, the fluxes at the offshore GRS site were negatively correlated to the significant wave height during the daytime, suggesting that waves facilitated respiration through the hydrodynamic forcing caused by wave orbitals (Koch \& Gust 1999, Reidenbach et al. 2007, Hansen \& Reidenbach 2012). This wave forcing was found to flush particulates and gases at greater rates than unidirectional flow velocities in seagrass beds (Koch \& Gust 1999, Hansen \& Reidenbach 2012) and to increase the flushing of coral canopies by $\sim 2.5$-fold over unidirectional flow velocities (Reidenbach et al. 2007). Hansen \& Reidenbach (2012) found that unidirectional flows decreased by $\sim 70 \%$ within the canopy of Zostera marina seagrass beds, but wave orbital velocities only decreased by $20 \%$. This suggests that waves may facilitate respiration in seagrass beds by enhancing transport through the canopy, while unidirectional flows may act to reduce respiration by limiting exchange with the lower canopy and sediment due to the bending of the seagrass blades. However, neither reduced respiration rates nor reduced canopy exchange were observed at the 2 highest velocity and biomass sites of GRS and RKB (Figs. 6 \& 9B) in this study. The interactions of these hydrodynamic processes with variations in seagrass canopy structure (e.g. density, leaf length, morphology, and species) are not well-understood and need further study to elucidate the effects of unidirectional flows and waves on in situ metabolic rates.

Suspended sediments that accumulated on seagrass blades and reduced the irradiance reaching the leaf surface also likely caused some of the observed flux variability that was not explained by other factors (Fig. 10). Under high-flow conditions sediments did not accumulate on the blades (Fig. 10A), but did so under low-velocity conditions (Fig. 10B) and likely reduced seagrass photosynthesis. Epiphytes also reduce light availability for seagrasses and affect productivity, especially in older blades (Orth \& van Montfrans 1984, Frankovich \& Zieman 2005), but epiphytes accumulate gradually and would not lead to daily or hourly variability. In contrast, the transient nature of accumulating sediment on blades of all
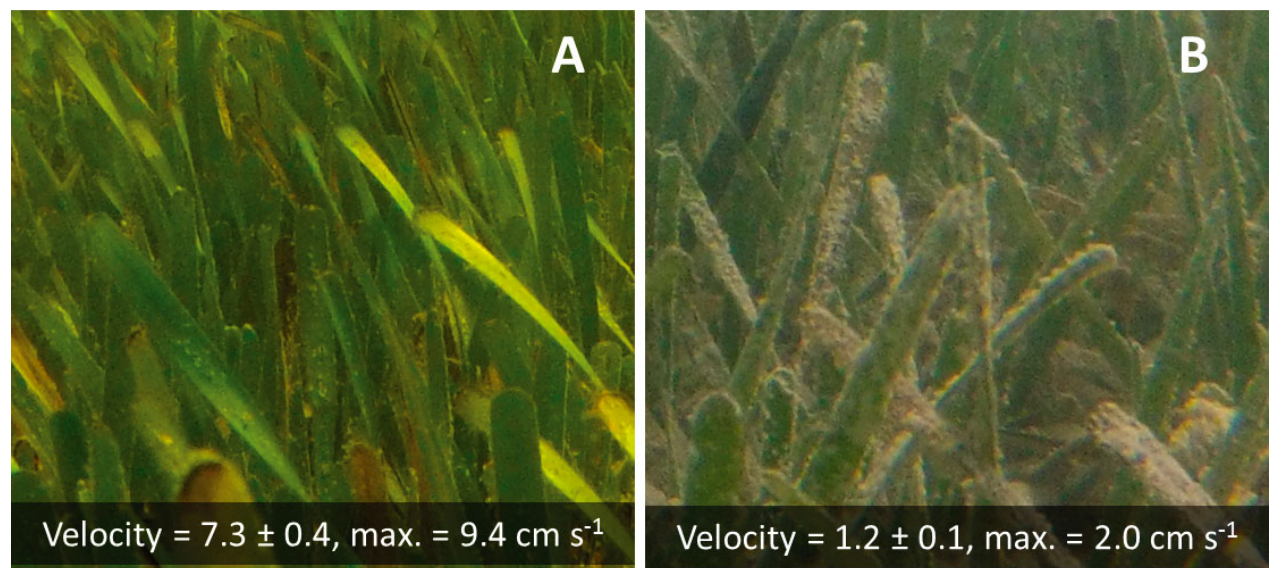

Fig. 10. Under low-velocity conditions, sedimentation on leaves reduces the light available to seagrass blades. (A) High flow rates at RKB likely reduced sediment deposition on leaves. (B) Sedimentation on leaves at site BA was observed often due to low-velocity conditions. The velocities are averages over $4 \mathrm{~h}$ prior to the picture being taken, and max. represents the maximum $0.25 \mathrm{~h}$ average velocity during the same period 
ages likely caused some of the variability in metabolism. Therefore, an in situ dynamic exists where no single parameter can explain ecosystem productivity, but all factors such as irradiance, flow velocity, waves, sedimentation, canopy structure, and epiphyte load must be considered when examining the variability of seagrass ecosystem metabolism.

\section{Florida Bay gradients}

The EC flux measurements were consistent with the established productivity and nutrient gradient across Florida Bay that has been related to phosphorus availability (Zieman 1989, Fourqurean \& Zieman 2002, Long et al. 2008). This phosphorus gradient was evident by amounts of total phosphorus, porewater phosphorus, and seagrass biomass present at each site (Table 1). The increases in NEM, GPP, and respiration determined by the $\mathrm{EC}$ technique were also consistent with the increasing phosphorus gradient, with the highest rates at RKB and the lowest at Duck (Fig. 3). There was also a salinity gradient across Florida Bay, as the northeast of the bay receives freshwater inputs from the Everglades, but the differences were within a range of 20 to 40 , which has been shown to have no influence on the productivity of $T$. testudinum in this location (Herbert \& Fourqurean 2009).

The highest average and instantaneous EC fluxes were both found at RKB and the lowest at Duck, despite RKB having the lowest average irradiance and Duck having the highest (Fig. $7 \mathrm{~F} \& \mathrm{H}$, respectively). The higher irradiance at Duck was at least partially due to the resuspension of fine, white carbonate mud, commonly referred to as 'whiting' (Robbins \& Blackwelder 1992). This highly reflective or highalbedo material caused significant turbidity at Duck, but resulted in more diffuse light and a higher overall irradiance, where the carbonate muds are analogous to tiny mirrors suspended in the water column (Fig. 1). The high biomass and shoot density of seagrasses at RKB reduced the flow at the benthos and allowed for the deposition and stabilization of the fine carbonate muds (Fonseca \& Fisher 1986, Gacia \& Duarte 2001), while the sparse shoot density and low biomass at Duck likely allowed the fine carbonate muds to be constantly resuspended by currents.

The different P-I relationship slopes across the sites were directly correlated to the nutrient-driven biomass gradient (Table 2, Fig. 5), indicating that the amount of photosynthetic surface area was also driving the efficiency of the P-I relationships (Zimmer- man 2003, Enriquez \& Pantoja-Reyes 2005, Ralph et al. 2007). The increasing photosynthetic surface area across Florida Bay also likely reduced the $I_{C}(200,239$, and $314 \mu \mathrm{mol}$ photons $\mathrm{m}^{-2} \mathrm{~s}^{-1}$ for RKB, BA, and Duck, respectively), because of the significant increase in photosynthesis per unit area relative to respiration. This is apparent from RKB, which has the lowest compensation point but also the highest average respiration rates (Fig. 3). While respiration was higher with greater amounts of nutrients, organic matter, and seagrass biomass, the autotrophy of seagrasses reduced the $I_{\mathrm{C}}$, due to the increase in photosynthesis per unit area relative to the respiratory demand of other heterotrophs in the seagrass ecosystem (i.e. net autotrophy). Further, $I_{\mathrm{c}}$ values indicate the irradiance where NEM is zero and, therefore, a reduction in $I_{c}$ for the higher biomass sites indicates that greater photosynthetic surface area contributes to net autotrophy of the seagrass meadow.

The total photosynthetic surface area dictated the efficiency of capturing light at the ecosystem level (Fig. 5). At the level of an individual shoot, the low density and biomass (here due to low nutrient conditions) results in less self-shading and therefore the potential to capture more light per leaf area compared to more dense meadows (Ralph et al. 2007). Conversely, at high seagrass densities and biomass there is a high amount of self-shading and seagrass blades capture less light per leaf area, but a large portion of the available light is utilized (Zimmerman 2003, Enriquez \& Pantoja-Reyes 2005). In Florida Bay the ambient phosphorus concentrations largely dictate the total amount of seagrass biomass (Fourqurean \& Zieman 2002). Therefore, the seagrass meadows with low density and biomass compensate for nutrient deficiency through enhanced light utilization per leaf area (e.g. Duck, Fig. 1). In contrast, the structure of high-density and -biomass seagrasses produces a high photosynthetic surface area to capture as much light as possible to support the large biomass (e.g. RKB, Fig. 1).

The variability of respiration rates and their drivers is particularly important to $\mathrm{C}$ cycling as two-thirds of the $\mathrm{C}$ in seagrass meadows is stored belowground (Fourqurean et al. 2012) and this contributes significantly to the ability of seagrass ecosystems to be net autotrophic (Duarte et al. 2010). The biomass gradient may have led to the differences in respiration through the stimulation of microbial activity by seagrass root $\mathrm{O}_{2}$ release (Pedersen et al. 1998, Frederiksen \& Glud 2006) and dissolved organic $C$ exudation (Holmer and Nielsen 1997, Long et al. 2008). However, no reduction in autotrophy (due to enhanced 
Table 4 . NEM by site types across south Florida ( \pm SE). GRS contained coral and seagrass sites. Benthic coverages were obtained from FDEP (1998) and Yarbro \& Carlson (2013). The number of $24 \mathrm{~h}$ measuring periods is represented by $n$. Net carbon exchange was determined using an approximate ratio of $1: 1$ for $\mathrm{C}: \mathrm{O}_{2}$. Reef metabolic measurements from Long et al. (2013)

\begin{tabular}{|llcccc|}
\hline Location & Site & $\mathrm{n}$ & $\begin{array}{c}\text { NEM } \\
\left(\mathrm{mmol} \mathrm{O}_{2}\right. \\
\left.\mathrm{m}^{-2} \mathrm{~d}^{-1}\right)\end{array}$ & $\begin{array}{c}\text { Coverage } \\
(\mathrm{Ha})\end{array}$ & $\begin{array}{c}\text { Net carbon } \\
\text { exchange } \\
\left(\mathrm{kg} \mathrm{d}^{-1}\right)\end{array}$ \\
\hline GRS & Seagrass & 5 & $37 \pm 31$ & 292520 & 1314 \\
Florida Bay & Seagrass & 27 & $24 \pm 15$ & 145300 & 413 \\
GRS & Reef slope & 5 & $-6 \pm 21$ & 8932 & -6 \\
GRS & Reef crest & 7 & $378 \pm 76$ & 42 & 2 \\
\hline
\end{tabular}

respiration) was observed here with increasing seagrass biomass or organic matter. Because the respiration and GPP rates from EC measurements are conservative estimates due to the assumption that daytime and nighttime respiration is equivalent (Hume et al. 2011, Long et al. 2013), further in situ research is required to evaluate how respiration rates influence $\mathrm{C}$ storage in seagrass beds. In future studies, the EC determination of respiration and GPP could be improved by comparisons with other techniques that specifically determine the daytime respiration or GPP, such as triple oxygen isotopes (Stanley \& Howard 2013).

Seagrass NEM represents a large component of the $\mathrm{C}$ cycling in south Florida as seagrasses cover nearly 450000 Ha (FDEP 1998) (Table 4). Our recent EC work (Long et al. 2013) on an adjacent shallow coral reef (200 $\mathrm{m}$ away from GRS site) showed that the concurrent reef production was an order of magnitude greater than the production at the GRS seagrass site $\left(\mathrm{NEM}=378\right.$ vs. $37 \mathrm{mmol} \mathrm{O}_{2} \mathrm{~m}^{-2} \mathrm{~d}^{-1}$, respectively). However, shallow coral reefs cover only $0.01 \%$ of the area that seagrasses cover across south Florida (FDEP 1998). Combining these daily rates with the total area for each ecosystem type reveals that the net $\mathrm{C}$ exchange during the summer is on the order of $1730 \mathrm{~kg} \mathrm{C} \mathrm{d}^{-1}$ for the seagrass meadows, with the rates for shallow reefs and reef slopes being 3 orders of magnitude lower (Table 4). This simple, first-order calculation illustrates that while shallow coral reefs may be highly productive, comparable to the most productive land-based ecosystems, and reef slopes may be heterotrophic (Long et al. 2013), these environments are very limited in spatial coverage. Therefore, even though seagrass meadows have much lower net productivity rates than reef systems, the large area that seagrasses cover makes them a significant component of coastal C cycling.

\section{CONCLUSIONS}

The rates of NEM, GPP, and respiration increased across Florida Bay and were consistent with the increasing phosphorus and biomass gradient across the sites. The observed short-term dynamics of seagrass metabolism were driven by variations in the irradiance, velocity, waves, and suspended sediments. Denser seagrass canopies led to increased sediment retention, higher light utilization efficiency, reduced solute exchange under low-flow conditions, higher rates of autotrophy, and linear non-saturating $\mathrm{P}-\mathrm{I}$ relationships. Our measurements highlight the importance of in situ ecosystem-scale measurements that integrate across the whole benthic environment and include variability due to changing environmental conditions, especially when metabolic rates are scaled up to whole-organism, ecosystem, and regional scales. For example, photosynthetic rates measured at a point on a seagrass blade under full light or flow conditions may exhibit a very different metabolic response than measurements that are integrated across the entire seagrass canopy and community. Further, the high variability over short time periods indicates that metabolic measurements must be conducted over sufficiently long periods (multiple days) to fully integrate this variability. This study also shows that the EC technique is a powerful approach for examining flow-canopy interactions under natural light conditions, and their influence on ecosystem metabolism. Future applications of EC should strive toward longer-term in situ monitoring, as is presently done in atmospheric EC measurements. These longer-term measurements will require the development of sensors that are more resistant to breakage and fouling, such as $\mathrm{O}_{2}$ optodes (Chipman et al. 2012).

Acknowledgements. This manuscript is dedicated to the memory and legacy of Joseph C. Zieman, a pioneer in seagrass ecology, whose curiosity, advice, and unwavering support had a significant influence on the lives of many graduate students and this work. Comments from 3 anonymous reviewers substantially improved this manuscript. We thank Jennie Rheuban for assistance in the field. This research was conducted under Florida Keys National Marine Sanctuary permit no. 2010-064 and Everglades National Park permit no. EVER-2011-SCI-0057. This study received financial support from the Jones Environmental and Barley Scholars Program at the University of Virginia and the National Science Foundation (Chemical Oceanography grant OCE0536431). 


\section{LITERATURE CITED}

Asner GP, Scurlock AM, Hicke JA (2003) Global synthesis of leaf area index observations: implications for ecological and remote sensing studies. Global Ecol Biogeogr 12: 191-205

Berg P, McGlathery KJ (2001) A high resolution porewater sampler for sandy sediments. Limnol Oceanogr 46: 203-210

> Berg P, Røy H, Janssen F, Meyer V, Jørgensen BB, Huettel $M$, de Beer D (2003) Oxygen uptake by aquatic sediments measured with a novel non-invasive eddy-correlation technique. Mar Ecol Prog Ser 261:75-83

Berg P, Roy H, Wiberg PL (2007) Eddy correlation flux measurements: the sediment surface area that contributes to the flux. Limnol Oceanogr 52:1672-1684

Berg P, Glud R, Hume A, Stahl H, Oguri K, Meyer V, Kitazato H (2009) Eddy correlation measurements of oxygen uptake in deep ocean sediments. Limnol Oceanogr Methods 7:576-584

Berg P, Long MH, Huettel M, Rheuban JE and others (2013) Eddy correlation measurements of oxygen fluxes in permeable sediments exposed to varying current flow and light. Limnol Oceanogr 58:1329-1343

Binzer T, Sand-Jensen K, Middleboe AL (2006) Community photosynthesis of aquatic macrophytes. Limnol Oceanogr 51:2722-2733

> Brand A, McGinnis DF, Wehrli B, Wuest A (2008) Intermittent oxygen flux from the interior into the bottom boundary of lakes as observed by eddy correlation. Limnol Oceanogr 53:1997-2006

Burba G (2013) Eddy covariance method. Li-COR Biogeosciences, Lincoln, NE

Cayabyab NM, Enriquez S (2007) Leaf photoacclimatory responses of the tropical seagrass Thalassia testudinum under mesocosm conditions: a mechanistic scaling-up study. New Phytol 176:108-123

> Chipman L, Huettel M, Berg P, Meyer V, Klimant I, Glud R, Wenzhoefer F (2012) Oxygen optodes as fast sensors for eddy correlation measurements in aquatic systems. Limnol Oceanogr Meth 10:304-316

Dawes CJ (1998) Marine botany. University of South Florida, Tampa, FL

Duarte CM (1995) Submerged aquatic vegetation in relation to different nutrient regimes. Ophelia 41:87-112

> Duarte CM, Marba N, Gacia E, Fourqurean JW, Beggins J, Barron C, Apostolake ET (2010) Seagrass community metabolism: assessing the carbon sink capacity of seagrass meadows. Global Biogeochem Cycles 24:GB4032, doi:10.1029/2010GB003793

> Durako MJ, Kunzelman JI (2002) Photosynthetic characteristics of Thalassia testudinum measured in situ by pulseamplitude modulated (PAM) fluorometry: methodological and scale-based considerations. Aquat Bot 73: 173-185

- Enriquez S, Merino M, Iglesias-Prieto R (2002) Variations in the photosynthetic performance along the leaves of the tropical seagrass Thalassia testudinum. Mar Biol 140: 891-900

Enriquez S, Pantoja-Reyes NI (2005) Form-function of the effect of canopy morphology on leaf shading in the seagrass Thalassia testudinum. Oecologia 145:234-242

Falter JL, Lowe RJ, Atkinson MJ, Monismith SG, Schar DW (2008) Continuous measurements of net production over a shallow reef community using a modified Eulerian approach. J Geophys Res 113:C07035, doi:10.1029/2007 JC004663

FDEP (Florida Department of Environmental Protection) (1998) Benthic habitats of the Florida Keys. FMRI Technical Report TR-4. Florida Department of Environmental Protection, St. Petersburg, FL

Finelli CM, Helmuth BS, Pentcheff ND, Wethy DS (2007) Intracolony variability in photosynthesis by corals is affected by water flow: role of oxygen flux. Mar Ecol Prog Ser 349:103-110

Fonseca MS, Fisher JS (1986) A comparison of canopy friction and sediment movement between four species of seagrass with reference to their ecology and restoration. Mar Ecol Prog Ser 29:15-22

Fonseca MS, Kenworthy WJ (1987) Effects of current on photosynthesis and distribution of seagrasses. Aquat Bot 27:59-78

> Fourqurean JW, Zieman JC (1992) Phosphorus limitation of primary production in Florida Bay: evidence from C:N:P ratios of the dominant seagrass Thalassia testudinum. Limnol Oceanogr 37:162-171

- Fourqurean JW, Zieman JC (2002) Nutrient content of the seagrass Thalassia testudinum reveals regional patterns of relative availability of nitrogen and phosphorus in the Florida Keys, USA. Biogeochem 61:229-245

Fourqurean JW, Willsie A, Rose CD, Rutten LM (2001) Spatial and temporal pattern in seagrass community composition and productivity in south Florida. Mar Biol 138: 341-354

Fourqurean JW, Duarte CM, Kennedy H, Marba N and others (2012) Seagrass ecosystems as a globally significant carbon stock. Nat Geosci 5:505-509

- Frankovich TA, Zieman JC (2005) A temporal investigation of grazer dynamics, nutrients, seagrass leaf productivity, and epiphyte standing stock. Estuaries 28:41-52

Frederiksen MS, Glud RN (2006) Oxygen dynamics in the rhizosphere of Zostera marina: a two-dimensional planar optode study. Limnol Oceanogr 51:1072-1083

Gacia E, Duarte CM (2001) Sediment retention by a Mediterranean Posidonia oceanica meadow: the balance between deposition and resuspension. Est Coast Shelf Sci 52:505-514

- Gacia E, Marba N, Cebrian J, Vaquer-Sunyer R, GarciasBonet N, Duarte CM (2012) Thresholds of irradiance for seagrass Posidonia oceanica meadow metabolism. Mar Ecol Prog Ser 466:69-79

Gattuso JP, Frankignoulle M, Wollast R (1998) Carbon and carbonate metabolism in coastal aquatic ecosystems. Annu Rev Ecol Syst 29:405-434

Gessner F (1971) The water economy of the sea grass Thalassia testudinum. Matrix Biol 10:258-260

Glud RN (2008) Oxygen dynamics of marine sediments. Mar Biol Res 4:243-289

Glud RN, Berg P, Hume A, Batty P, Blicher ME, Lennert M, Rysgaard S (2010) Benthic oxygen exchange across hard-bottom substrates quantified by eddy correlation in a sub-Arctic fjord. Mar Ecol Prog Ser 417:1-12

> Hansen JCR, Reidenbach MA (2012) Wave and tidally driven flows in eelgrass beds and their effect on sediment suspension. Mar Ecol Prog Ser 448:271-287

> Herbert DA, Fourqurean JW (2009) Phosphorus availability and salinity control productivity and demography of the seagrass Thalassia testudinum in Florida Bay. Estuaries Coasts 32:188-201

Holmer M, Nielsen SL (1997) Sediment sulfur dynamics 
related to biomass-density patterns in Zostera marina (eelgrass) beds. Mar Ecol Prog Ser 146:163-171

- Hume AC, Berg P, McGlathery KJ (2011) Dissolved oxygen fluxes and ecosystem metabolism in an eelgrass (Zoster marina) meadow measured with the eddy correlation technique. Limnol Oceanogr 56:86-96

> Johnson KS, Barry JP, Colette LJ, Fitzwater SE, Jannasch HW, Lovera CF (2011) Nitrate and oxygen flux across the sediment-water interface observed by eddy correlation measurements on the open continental shelf. Limnol Oceanogr Methods 9:543-553

Koch EW, Gust G (1999) Water flow in tide- and wavedominated beds of the seagrass Thalassia testudinum. Mar Ecol Prog Ser 184:63-72

Koroleff L (1983) Determination of phosphorus. In: Grashoff K, Ehrhardt M, Kremling K (eds) Methods of seawater analysis. Verlag-Chemie, Weinheim

> Lavery PS, McMahon K, Mulligan M, Tennyson A (2009) Interactive effects of timing, intensity and duration of experimental shading on Amphibolis griffithii. Mar Ecol Prog Ser 394:21-33

> Lee K, Park SR, Kim YK (2007) Effects of irradiance, temperature, and nutrients on growth dynamics of seagrasses: a review. J Exp Mar Biol Ecol 350:144-175

> Long MH, McGlathery KJ, Zieman JC, Berg P (2008) The role of organic acid exudates in liberating phosphorus from seagrass-vegetated carbonate sediments. Limnol Oceanogr 53:2616-2626

Long MH, Rheuban J, Berg P, Zieman JC (2012) A comparison and correction of versatile and economical light loggers to photosynthetically active radiation sensors. Limnol Oceanogr Methods 10:416-424

Long MH, Berg P, de Beer D, Zieman JC (2013) In situ coral reef oxygen metabolism: an eddy correlation study. PLoS ONE 8:e58581

Mackey P, Collier CJ, Lavery PS (2007) Effects of experimental reduction of light availability on the seagrass Amphibolis griffithii. Mar Ecol Prog Ser 342:117-126

Mass T, Genin A, Shavit U, Grinstein M, Tchernov D (2010) Flow enhances photosynthesis in marine benthic autotrophs by increasing the efflux of oxygen from the organism to the water. PNAS 107:2527-2531

> McGinnis DF, Cherednichenko S, Sommer S, Berg P and others (2011) Simple, robust eddy correlation amplifier for aquatic dissolved oxygen and hydrogen sulfide measurements. Limnol Oceanogr Methods 9:340-347

Motulsky H, Christopoulos A (2004) Fitting models to biological data using linear and nonlinear regression: a practical guide to curve fitting. Oxford University Press, New York, NY

> Nepf HM (2012) Flow and transport in regions with aquatic vegetation. Annu Rev Fluid Mech 44:123-142

> Orth RJ, van Montfrans J (1984) Epiphyte-seagrass relationships with an emphasis on the role of micrograzing: a review. Aquat Bot 18:43-69

> Pedersen O, Borum J, Duarte CM, Fortes MD (1998) Oxygen dynamics in the rhizosphere of Cymodocea rotundata. Mar Ecol Prog Ser 169:283-288
Precht E, Huettel M (2003) Advective pore-water exchange driven by surface gravity waves and its ecological implications. Limnol Oceanogr 48:1674-1684

Ralph PJ, Durako MJ, Enriquez S, Collier CJ, Doblin MA (2007) Impact of light limitation on seagrasses. J Exp Mar Biol Ecol 350:176-193

Reidenbach MA, Koseff JR, Monismith SG (2007) Laboratory experiments of fine-scale mixing and mass transport within a coral canopy. Phys Fluids 19:075107

Reimers CE, Stecher HA, Taghon GL, Fuller CM and others (2004) In situ measurements of advective solute transport in permeable shelf sands. Cont Shelf Res 24:183-201

Revsbech NP (1989) An oxygen microsensor with a guard cathode. Limnol Oceanogr 34:474-478

- Rheuban JE, Berg P (2013) The effects of spatial and temporal variability at the sediment surface on aquatic eddy correlation flux measurements. Limnol Oceanogr Methods 11:351-359

Rheuban JE, Berg P, McGlathery KJ (2014a) Multiple timescale processes drive ecosystem metabolism in eelgrass (Zostera marina) meadows. Mar Ecol Prog Ser 507:1-13

Rheuban JE, Berg P, McGlathery KJ (2014b) Ecosystem metabolism along a colonization gradient of eelgrass (Zoster marina) measured by eddy correlation. Limnol Oceanogr 59:1376-1387

Robbins LL, Blackwelder PL (1992) Biochemical and ultrastructural evidence for the origin of whitings: a biologically induced calcium carbonate precipitation mechanism. Geology 20:464-468

Sand-Jensen K, Binzer T, Middleboe AL (2007) Scaling of photosynthetic production of aquatic macrophytes-a review. Oikos 116:280-294

Stanley RH, Howard EM (2013) Quantifying photosynthetic rates of microphytobenthos using the triple isotope composition of dissolved oxygen. Limnol Oceanogr Methods 11:360-373

Wiberg PL, Sherwood CR (2008) Calculating wave-generated bottom orbital velocities from surface-wave parameters. Comput Geosci 34:1243-1262

> Yarbro LA, Carlson PR (2008) Community oxygen and nutrient fluxes in seagrass beds of Florida Bay, USA. Estuaries Coasts 31:877-897

Yarbro LA, Carlson PR (eds) (2013) Seagrass integrated mapping and monitoring program: mapping and monitoring report number 1. Technical Report TR-17. Fish and Wildlife Research Institute, St. Petersburg, FL

Ziegler S, Benner R (1998) Ecosystem metabolism in a subtropical, seagrass-dominated lagoon. Mar Ecol Prog Ser 173:1-12

Z Zieman JC (1974) Methods for the study of the growth and production of the turtle grass, Thalassia testudinum. Aquaculture 4:139-143

Zieman JC (1989) Distribution, abundance and productivity of seagrasses and macroalgae in Florida Bay. Bull Mar Sci 44:292-311

Zimmerman RC (2003) A biooptical model of irradiance distribution and photosynthesis in seagrass canopies. Limnol Oceanogr 48:568-585

Submitted: May 6, 2014; Accepted: April 18, 2015

Proofs received from author(s): June 1, 2015
Editorial responsibility: Just Cebrian,

Dauphin Island, Alabama, USA 